Corporate social responsibility and systematic risk: International evidence

\begin{tabular}{|r|l|}
\hline Journal: & Journal of Risk Finance \\
\hline Manuscript ID & JRF-07-2020-0162.R1 \\
\hline Manuscript Type: & Applied Research Paper \\
\hline Keywords: & beta, systematic risk, corporate social responsibility, sustainability \\
\hline \multicolumn{2}{|l}{} \\
\hline
\end{tabular}

SCHOLARONE $^{\mathrm{m}}$
Manuscripts $^{\text {Manus }}$ 


\title{
Corporate social responsibility and systematic risk: International evidence
}

\begin{abstract}
Design/methodology/approach - This study focuses on the impact of corporate social responsibility on systematic firm risk in an international sample. We measure corporate social performance (CSP) emerging from a company's social responsibility efforts by utilizing a CSP rating framework that covers a variety of dimensions. The instrumental variable approach is applied to mitigate endogeneity and identify causal relationships.

Purpose - This paper aims to close gaps in the current literature according to whether there are differences regarding the relationship between CSP and systematic risk when diverse regions of the world are considered, and what the respective drivers for this relationship are. Furthermore, it tests the robustness to alternative measures for CSP and systematic risk.

Findings - The impact of overall CSP on systematic risk is most distinct for North American firms and, in descending order, weaker in Europe, AsiaPacific, and Japan. Risk mitigation applies across all four regions. However, the magnitude of impact differs. While the most critical drivers in North America and Japan include product responsibility, Europe is affected most by the employees category and Asia-Pacific by environmental innovation.

Practical implications - Our findings help firms to control their cost of equity and investors may identify low-risk stocks by considering certain aspects of CSP.

Originality/value - This study distinguishes itself from previous literature addressing the connection between systematic risk and CSP by focusing on regional differences in an international sample, using the very transparent CSP measures of Asset4, identifying underlying impact drivers, and testing for robustness to alternative measures of systematic risk.
\end{abstract}




\section{Introduction}

Current literature cannot answer whether the impact of corporate social performance (CSP) on systematic risk differs across diverse regions of the world, and what the respective drivers for this relationship are. We provide empirical evidence of the impact of CSP on systematic risk in an international sample comprising firms in North America, Europe, Japan, and the Asia-Pacific region. Our notion of systematic risk is based on the capital asset pricing model (CAPM) of Sharpe (1964), Lintner (1975), and Mossin (1966). This study distinguishes itself from previous literature addressing the connection between systematic risk and CSP in four ways: 1) it focuses on regional differences in an international sample; 2) it uses the very transparent CSP measures of Asset4; 3) it identifies underlying impact drivers; and 4) it investigates whether these results are robust to alternative measures of systematic risk developed from the five-factor asset pricing model of Fama and French (2015) and the international CAPM. As a result, we find a strong risk mitigation effect in North America and in Europe and, to a lesser extent in Japan and Asia-Pacific. Although the magnitude of impact differs, identified drivers include emission reduction, environmental innovation, resource reduction, product responsibility, community, human rights, diversity, and employees.

While the risk mitigation view assumes that firms profit from investments in CSP through lower risk, the over-investment view claims that these investments must are sunk costs without any further benefits (Goss and Roberts, 
2011). The impact of CSP on corporate risk is the object of current research. Recent examples are studies focussing on credit risk (cf. Attig et al., 2013; Stellner et al., 2015; Jiraporn et al., 2014), idiosyncratic and crash risk (cf. Utz, 2018; Kim et al., 2014; Lee and Faff, 2009), and systematic risk (cf. Albuquerque et al., 2018; Sassen et al., 2016).

Although there is some initial empirical evidence concerning the impact of CSP on systematic risk for the U.S. (Albuquerque et al., 2018), and Europe (Sassen et al., 2016), the current literature cannot answer whether there are differences regarding this relationship when diverse regions of the world are considered, and what the respective drivers for this relationship are. Furthermore, it is not clear whether the existing results, which are based on the previously mentioned CAPM, are robust to alternative measures for CSP and systematic risk. Our analysis closes this gap in the literature by analyzing the impact of Asset4 CSP measures on a more granular level based on a world-wide sample. Robustness checks include the five-factor model of Fama and French (2015) and the international CAPM (Fama and French, 2012) to estimate the systematic risk. As the measures for CSP are expected to be highly endogenous, we apply an instrumental variable approach with a large set of control variables and time, industry, and country fixed effects to endogenize the CSP measures. Instruments include CSP country averages (Jiraporn et al., 2014) and relevant categories of the National Business Systems (NBS) classification (Ioannou and Serafeim, 2012; Whitley, 1999).

Finally, we find a negative relationship between CSP and systematic risk 
in North America, Europe, Japan, and Asia-Pacific, indicating that high CSP has a tendency to be connected to low systematic risk and vice versa. Thus there is evidence for the risk mitigation hypothesis independently of the region. The impact of CSP is strongest in North America, followed by Europe, Asia-Pacific, and Japan. We see that this pattern is driven mainly by the contribution of all CSP components but to a varying extent. Product responsibility is most important in North America and Japan, employees in Europe, and environmental innovation in Asia-Pacific.

Our findings on the international empirical evidence of CSP impact on systematic risk also have implications for practice, as the systematic risk of a firm is the major component when it comes to determining the cost of equity. Also, investors may identify low risk stocks by considering certain aspects of CSP.

The remainder of the paper is organized as follows. We start with some theoretical considerations about the relationship between CSP and systematic risk in Section 2. Section 3 describes the global data set, and Section 4 introduces the employed instrumental variable methodology. Section 5 presents the empirical results for both the entire sample and each region. Finally, Section 6 concludes including practical implications for capital allocation, investment valuation, and portfolio selection. 


\section{Theoretical Considerations}

In the literature, two opposite views have emerged from examining whether firms benefit from investments in CSP, namely the risk mitigation view and the over-investment view (Goss and Roberts, 2011). In particular, there is evidence that firms profit from sustainable future cash flows (Kang et al., 2016; Dorfleitner et al., 2018; Von Arx and Ziegler, 2014) and abnormal returns (Flammer, 2015), especially in consumer-oriented industries (Dimson et al., 2015). Stock returns of high CSP firms may be comparably higher even during a financial crisis, as documented for the financial crisis of 2008/2009 by Lins et al. (2017), which implies that CSP can contribute to mitigating risk. In a meta-study, Orlitzky et al. (2003) find a positive relationship between ESG and CFP in the majority of studies. Referring to firm value, Margolis et al. (2007), in a meta-study comprising the evidence of 35 years, find, on average, a small, positive effect. Servaes and Tamayo (2013) provide evidence for a positive impact of CSP on firm value for firms with high levels of customer awareness. Bauer and Hann (2010) examine the risk related to environmental performance and find that unsustainable firms can be endangered regarding reputation, legal, and regulatory risks. Firms with an excellent performance in social categories may hire talented employees more easily, which is crucial to economic success (Turban and Greening, 1997). For completeness, we note that there is also evidence of the over-investment view, albeit less comprehensive (cf. Brammer and Millington, 2008; Cornell and Shapiro, 1987; Aupperle et al., 1985). 
The relationship between CSP and a variety of risk aspects has already been subject to previous empirical research. Attig et al. (2013) and Jiraporn et al. (2014) analyze the impact of CSP on credit risk and find strong effects in North America. Utz (2018) finds evidence of the risk mitigation view of CSP for idiosyncratic and crash risk in the U.S., Japan, and Europe, while the over-investment view applies to Asia-Pacific. Furthermore, high CSP appears to be consistent with a lower cost of equity (Goss and Roberts, 2011; Dhaliwal et al., 2011; El Ghoul et al., 2011; Lee et al., 2009; Orlitzky, 2008).

Referring to the relationship between CSP and systematic risk, Albuquerque et al. (2018) find a clear risk-mitigating impact of CSP for firms located in the U.S. Their analysis is methodologically based on the overall CSP measurement of KLD, the CAPM to calculate systematic risk, and an instrumental variable approach to confirm the relationship between both. Besides the empirical aspects, they largely contribute to the literature by deducing an industry equilibrium model in which firms have the option to choose a sustainable or unsustainable production method as part of their product differentiation. Sassen et al. (2016) provide some preliminary evidence on systematic risk for European firms based on Asset4 CSP measures, however, do not use an instrumental variable approach. From the previous literature in the context of CSP affecting corporate performance, cost of equity, and various types of risk, we can clearly formulate the expectation that CSP is negatively related to systematic risk, even for companies outside the 
U.S. and regardless of how CSP is measured.

To formulate an expectation on regional variations in the relationship between CSP and systematic risk, we consider the international evidence on different levels of CSP and on the link between CSP and other types of risk. For idiosyncratic and credit risk, it is already known that the relation with CSP varies across regions, while CSP itself also varies (cf. Utz (2018) for the case of idiosyncratic risk and Dorfleitner et al. (2020) for the case of credit risk). Although credit risk, idiosyncratic risk, and systematic risk are different concepts in general, they are still loosely related. ${ }^{1}$ Thus, it is plausible to expect that also the relationship of CSP and systematic risk could differ across regions, given that there is an impact.

\section{Data}

We analyze the relationship between the annual CSP measures of Asset4 and annual measures for systematic risk for the regions of North America, Europe, Japan, and Asia-Pacific. Table 1 shows the distribution of the sample based on 3800 companies across regions. In the pre-step, we employ a dataset of weekly stock returns, market returns, and three-months risk-free rates on the country level to estimate the systematic risk of one year. ${ }^{2}$ Table 2

\footnotetext{
${ }^{1}$ One linking concept is the financial leverage of the firm, as credit risk (Merton, 1974), idiosyncratic risk (Brandt et al., 2010), and systematic risk (Hamada, 1972) are influenced by the financial leverage. Generally, the risk management of a company includes a simultaneous consideration of all three kinds of risk.

${ }^{2}$ While Albuquerque et al. (2018) use daily stock returns within one year to calculate the systematic risk, we refrain from doing so due to autocorrelation issues. We use weekly
} 
presents an overview of the utilized data sources in this step. In the following step, the main regressions are based on a yearly panel dataset, including the systematic risk measures from the pre-step matched with CSP measures, instruments, and control variables. The observation period ranges from 2003 to 2018 for the dependent variable systematic risk and from 2002 to 2017 for the explanatory variables due to a lag of one period. The sample includes all publicly traded firms from the regions of North America, Europe, Japan, and Asia-Pacific as defined by Fama and French (2012) for which Asset4 scores are available.

In our analysis, systematic risk is proxied by the market index beta coefficient of the capital asset pricing model (CAPM) (cf. Albuquerque et al., 2018). The distribution of estimated alphas and betas is displayed in Table 3. The predominant share of alphas is not significantly different from zero. For this reason, we focus on the beta only in the following. The mean beta of North America is the highest of all regions, and Europe is lowest while Japan and Asia-Pacific rank in-between.

We choose the annually updated CSP scores of Asset4 provided by Thomson Reuters for our analysis because of their excellent reputation, transparency, and international availability. While the popular MSCI-KLD database is only available for the U.S., Asset4 scores are available for firms on a global

returns to solve this issue as for monthly returns too few data points result, given the estimation window of one year, which is necessary due to the frequency of the explanatory data in the main regressions. 
basis. The reputation of these scores has been demonstrated in several studies (e.g., Stellner et al., 2015). Compared with KLD, FTSE4Good, and Dow Jones, CSP measures of Asset4 provide more transparency (Chatterji and Levine, 2006). Based on publicly available sources such as websites, SEC filings such as 10-K, DEF 14A, 10-Q, sustainability reports, media sources, and NGO reports, Asset4 evaluates more than 750 individual questions leading to a data point in each case. The information is then aggregated to more than 250 key performance indicators. These are again condensed to 18 categories for the aggregated pillars of environmental, social, economic sustainability, and corporate governance performance. Following major studies in this area (cf. El Ghoul et al., 2017; Ioannou and Serafeim, 2012; Luo et al., 2015), we refrain from using the economic sustainability and the corporate governance scores to adhere to a narrow and clear definition of CSP and utilize the average of the environment and social scores to determine the overall CSP. The category level of social scores is matched to categories of product responsibility, community, human rights, diversity, and employees as in Attig et al. (2013). The environmental performance is marked by three categories, namely emission reduction, environmental innovation, and resource reduction as in Dorfleitner et al. (2018). Details of the CSP variables are also provided in Table 4.

Table 5 provides descriptive statistics for the employed CSP variables, their instruments, and control variables for the four regional panels. The set of variables displays substantial differences across the regions. Note that the 
mean of overall CSP ranks highest in Europe (64\%), lowest in North America, and Asia-Pacific (43\% both), while Japan (58\%) is in-between. Details of the instrument variables are provided in Table 6.

Analogous to Albuquerque et al. (2018), we control for several other explanatory variables (see Table 7). An influence on credit risk has been evidenced for leverage, size, and earnings variability (Beaver et al., 1970) and for research and development (R\&D) expenditures (McAlister et al., 2007). As there are indications that diversified firms have higher betas than undiversified firms (Melicher and Rush, 1973), we proxy this effect by the number of secondary 3-digit ISIC codes that Datastream provides besides the primary industry code. As firms retaining higher cash appear to face higher systematic risk (Palazzo, 2012), we include cash holdings as a variable. Because there is evidence that firms' operating leverage levels are related to their financial performance (Novy-Marx, 2010), we include the referring variable. The impact of capital expense on systematic risk is documented by Lev (1974). Thus we control for this variable also. We also include industryfixed effects based on the classification of Fama and French. ${ }^{3}$ An overview of industries in the sample is provided in Table 8. Additionally, we control for country- and time-fixed effects. All time-dependent explanatory variables are lagged by one year.

\footnotetext{
${ }^{3}$ The classification into ten industries based on firm SIC codes was obtained from the website http://mba.tuck.dartmouth.edu/pages/faculty/ken.french/index.html.
} 


\section{Methodology}

We aim to measure the impact of CSP on systematic firm risk. The systematic risk of stock $i$ is estimated based on its weekly returns $r_{i, s}$ according to the formula:

$$
r_{i, s}-r_{s}=\alpha_{i}+\beta_{i}\left(r_{M, s}-r_{s}\right)+\epsilon_{i, s}
$$

where $s=1, \ldots, 52$ describes the week of observation, $r_{s}$ the risk-free rate, and $r_{M, s}$ the market index return on the same week $s$. Finally, the systematic risk of firm $i$ in the respective year is found by the estimated value of $\beta_{i}$. Both alphas and betas are tested for significance based on the Newey-West estimator (Newey and West, 1986).

The measurement of the impact of CSP on systematic risk is based on two-stage least squares (2SLS) estimations, which implement an instrumental variable approach to overcome the endogeneity of the CSP measures. The ordinary least squares (OLS) regression in the first stage includes one respective CSP measure $x_{i, t-1}$ as the dependent variable, e.g., the resources CSP model consists of the resources CSP measure. Furthermore, the model considers a vector of instrument variables $\boldsymbol{z}_{i, t-1}$ (e.g., the average country CSP performance) and a vector of control variables $\boldsymbol{c}_{i, t-1}$ (including time-fixed and country-fixed effects and industry dummies) as explanatory variables:

$$
x_{i, t-1}=\boldsymbol{z}_{i, t-1} \boldsymbol{\gamma}_{z}+\boldsymbol{c}_{i, t-1} \boldsymbol{\gamma}_{c 1}+\epsilon_{1, i, t-1}
$$

To account for the panel structure of our (yearly) data, standard errors are 
clustered on the firm level. In the second stage, we regress systematic risk on the CSP estimates of stage one $\hat{x}_{i, t-1}$ as well as the same control variables vectors $\boldsymbol{c}_{\boldsymbol{i}, \boldsymbol{t}-\mathbf{1}}$ :

$$
\hat{\beta}_{i, t}=\hat{x}_{i, t-1} \gamma_{x}+\boldsymbol{c}_{i, t-1} \gamma_{c 2}+\epsilon_{2, i, t}
$$

Again we use OLS estimations with clustered standard errors on the firm level. All explanatory variables are lagged by one period.

\section{Empirical tests}

To commence, we analyze the impact of overall CSP on systematic risk followed by the breakdown into single CSP components. We then analyze the effect of integrating non-linear CSP terms into our model because some arguments favor a convex relationship between CSP and risk (Utz, 2018). Subsequently, we examine the robustness of our results.

\subsection{Varied impact of overall CSP across regions}

Table 9 provides the result of regressing systematic firm risk on overall CSP for North America, Europe, Japan, and Asia-Pacific based on 2SLS. The first (second) of each regional pair columns displays the first (second) stage regression. Additionally, we provide a test on weak instruments (low p-values indicate strong instruments) and $R^{2}$ values to measure model fit.

The estimations reveal a substantial impact of overall CSP on systematic risk on a significance level of $1 \%$ in the North American and European samples. However, the effect in Japan and Asia-Pacific is less pronounced but 
still significant on a $5 \%$ level. The sign of each CSP coefficient is negative, suggesting that an increase of overall CSP tends to correlate with a decrease in systematic risk. Thus the risk mitigation view is supported throughout all regions. Although all these coefficients are sufficiently significant and reveal negative signs, their impact differs according to the area. The effect is most potent in North America, half as strong in Europe, and in descending order weaker in Asia-Pacific and Japan. In all estimation sets, we include the average country CSP performance (Jiraporn et al., 2014) in stage one, which appears to be highly significant in all regions except Europe. For Europe and Asia-Pacific, we include further instruments (anti-self-dealing index, absence of corruption, political orientation, union density, skilled labor, power distance, and individualism) according to Ioannou and Serafeim (2012) as these regions include several countries with a heterogeneous orientation towards CSP. We test the results of Table 9 for multicollinearity based on the variance inflation factors (VIF); Table 10 thus presents the results of an estimation after variable selection so that only those with VIF below 10 are contained. Discarded instruments appear as non-significant when they are included in the model. The goodness of fit in terms of $R^{2}$ in both estimations is almost identical. For completeness, all instruments are included in further calculations. All control variables show reasonable signs within the expected range.

Our analysis mainly extends the valuable work of Albuquerque et al. (2018) in terms of international evidence. The analysis of the impact of 
overall CSP on systematic risk for firms located in North America forms the intersection between the research of Albuquerque et al. (2018) and ours. Although following a different CSP measurement approach, we find similar significant empirical evidence of the risk-mitigating effect of CSP on systematic risk. Thus, the CSP measurement concept appears to have no impact upon the findings of a negative relationship. The analysis of Sassen et al. (2016) also finds an overall impact of CSP on systematic risk for European firms. However, their more granular results are less reliable due to potential endogeneity problems.

Our findings suggest that returns of high CSP firms are less affected by systematic risk, from which one can deduce that these firms could also participate less in the positive long-term performance of the market. However, several studies find a positive relationship between CSP and corporate financial performance (CFP) (e.g., Kang et al., 2016; Von Arx and Ziegler, 2014). As a reconciliation of both effects, we consider the idea that high CSP firms can possibly retain their industry-specific level of returns (such as high expected returns, e.g., for technology firms, lower expected returns, e.g., for suppliers), while lowering their market beta. If such an effect is in place, then lower systematic risk can accompany positive abnormal returns in terms of a positive $\alpha$ in (5). 


\subsection{Identifying the Drivers of Risk Mitigation}

In the following, we extend the analysis from overall CSP to single components of CSP. Following Attig et al. (2013), we choose the categories of product responsibility, community, human rights, diversity, and employees and add emission reduction, environmental innovation, and resource reduction instead of only the aggregated environmental pillar based on Dorfleitner et al. (2018). In reference to the model specification, the overall CSP from the estimations in section 5.1 is now replaced by one of these categories, resulting in eight further 2SLS regression sets for each region. Tables 11 and 12 present individual stand-alone estimation results on the North America, Europe, Japan, and Asia-Pacific samples respectively.

In North America, all CSP components unanimously reveal a strong significance on a $1 \%$ level. The same is true for Europe except for the product responsibility category, which is significant on a $5 \%$ level. Japan indicates a significant influence of all CSP components on a level of 5\%. Asia-Pacific reveals significant strong effects for the employees category $(1 \%)$, followed by emission, environmental innovation, community, and diversity. Like the coefficients for overall CSP, all coefficients of CSP components show negative signs in all regional panels, thus, the risk mitigation view is confirmed for all cases of our analysis. However, considerable variations manifest themselves in the impact contribution of the single CSP components. In North America and Japan, the product responsibility category has by far the most definite impact compared with the other CSP components. Possible explanations in- 
clude that, in these markets, customers show more appreciation for product reliability (as mirrored, e.g., by the high number of product liability lawsuits in the U.S. and the corresponding legal opinion of strong consumer protection according to Goodden (2009)). At the same time, social or environmental aspects are more attractive elsewhere. In Europe, employees appear to be decisive. Environmental innovation turns out to be the most driving component in Asia-Pacific, possibly because firms' ecological protection standards have been enhanced by globalization (Chapple and Moon, 2005) and thus might have become increasingly important for economic success. By comparing the coefficients' magnitude of each CSP component between the regions, we recognize a similarity to the findings on the overall CSP. The effect is strongest in North America and weaker in Europe, Asia-Pacific, and Japan in descending order. Following the credit-risk argumentation of Attig et al. (2013), the impact could ultimately rely on what is socially desired, and this appears to be different for each of our regions. Although North America and Europe appear to be comparable when referring to cultural aspects, the impact of CSP is stronger in North America. This difference seems plausible because the lower mean level and higher standard deviation level may allow North American firms to distinguish themselves positively from one another while the CSP distribution in Europe is less widespread on a high level. In Japan and Asia-Pacific, CSP is apparently not as meaningful as in Western countries. When comparing our results with the findings of Utz (2018), who explores idiosyncratic risk, we perceive a certain level of consistency in terms 
of confirmation of the risk mitigation view in North America, Europe, and Japan. However, the over-investment hypothesis in Asia-Pacific, as found for idiosyncratic risk, cannot be observed for systematic risk. Compared with the findings of Attig et al. (2013) on credit risk, which find relevance of the employees, diversity, product responsibility, community, and environment categories, we also find human rights and hence all categories relevant. We apply their argument, which states that those CSP dimensions that are socially desired and related to the primary stakeholders have an impact, remains true. The explanation of (Attig et al., 2013) states that the CSP components improve the quality of firm information, mitigate agency cost, and express their ethical standards. This reasoning could also apply here.

\subsection{The incremental contribution of CSP components}

Utz (2018) identifies several reasons for a non-linear relationship between CSP and idiosyncratic risk. For example, one possible explanation of these can be derived from the work of McWilliams and Siegel (2001) who conclude the existence of an optimal level of CSP, implying that higher or lower levels lead to more disadvantages and fewer advantages. As these kind of considerations could also apply in our context, we consider the same for systematic risk. Thus, a squared CSP term $\hat{x}_{i, t-1}^{2}$ is integrated into our second stage models in addition to the linear term $\hat{x}_{i, t-1}$ yielding:

$$
\hat{\beta}_{i}=\hat{x}_{i, t-1} \gamma_{\hat{x}}+\hat{x}_{i, t-1}^{2} \gamma_{\hat{x}^{2}}+\boldsymbol{c}_{\boldsymbol{i}, \boldsymbol{t}-\mathbf{1}} \gamma_{\boldsymbol{c 2}}+\epsilon_{2, i, t}
$$


Table 13 presents the coefficients for both linear and squared CSP measures. For each region, all coefficients of linear and squared CSP show significance on a $1 \%$ level, while the model fit measured by $R^{2}$ is on a comparable high level. Although the coefficients in Table 13 generally imply inverted Ushaped relationships in form of a parabola in all four regions, the economic significance in our context depends on the location of the vertex (location between 0 and 100). Indeed, we observe that this shape is only considerably dominant in Asia-Pacific for the emission, resources, human rights, and employees categories as shown in Figure 1. We conclude that, in Asia-Pacific, the over-investment view pertains for low levels of CSP, thereby suggesting that increases in CSP lead to higher systematic risk. For higher levels of CSP, the risk mitigation view holds. For all other regions and CSP categories, the systematic risk simply decreases over the level of CSP.

\subsection{Robustness checks}

We apply robustness checks in each step of our analysis: in the regression aimed at measuring systematic risk as well as in the first and second stage of measuring the exogenous impact of CSP on systematic risk based on the 2SLS estimation.

While our main analysis is based on beta factors calculated by the CAPM, we conduct the same analysis based on the five-factor asset pricing model of Fama and French (2015). The latter considers the market return $r_{m, t}$ over the risk-free rate $r_{f, t}$ analogous to the CAPM and other factors regarding the 
stock size small minus big, $S M B$ ), value and growth (high minus low, $H M L$ ), operating profitability (robust minus weak, $R M W$ ), and investment attitude (conservative minus aggressive, $C M A$ ) for day $t$ are included, resulting in the following regression.

$$
r_{i, t}-r_{f, t}=\alpha_{i}+\beta_{1, i}\left(r_{m, t}-r_{f, t}\right)+\beta_{2, i} S M B_{t}+\beta_{3, i} H M L_{t}+\beta_{4, i} R M W_{t}+\beta_{5, i} C M A_{t}+\epsilon_{i, t}
$$

With betas according to this approach, the findings of our main analysis are confirmed in large parts, which can be seen in Table 14. In North America and Europe, again, overall CSP and all components are significant for the market factor. The same is true for Asia-Pacific except for the diversity category. There are no significant effects in Japan.

The results prove also robust if the beta is derived from the international CAPM (Fama and French, 2012) as seen in Table 15. In contrast to the employed variant of the CAPM, the international CAPM uses a single market index (we use the same dataset as described by Fama and French (2012)) instead of local market indices.

Next, we replace the CSP country average as an instrumental variable in the North American panel by the average CSP on the state level as another robustness check. Again, all CSP coefficients remain significant on a 1\% level. Further robustness checks address both the first and second stages of the main 2SLS regressions by adding additional control variables derived from previous research concerning CSP and credit risk. As there is consensus that all claims on assets should earn the same compensation per unit of risk 
(Merton, 1974; Campbell et al., 2008; Friewald et al., 2014), these variables may also matter for systematic risk. In particular, established companies tend to have better ratings (Fons, 1994), expressing lower risk. Hence we add the retained earnings to total assets ratio as it can be used to proxy a company's life cycle phase (DeAngelo et al., 2006). Furthermore, we include tangibility (proxied by power, plant, and equipment divided by total assets), the market-to-book ratio and a dividend dummy (1 if the firms paid dividends in the respective year, 0 otherwise) as there is empirical evidence of an impact of these variables on credit-risk (Rampini and Viswanathan, 2013; Pástor and Pietro, 2003; Hoberg and Prabhala, 2009). Table 16 presents the coefficients and significance levels. None of these modifications lead to significantly different results compared to our primary analysis.

Moreover, we include an interaction term between CSP and a dummy for industries included in "NAICS Codes of Environmental Sensitive Industries" published by the U.S. Small Business Administration as the environmental sensitivity of the industry appears to matter (Sassen et al., 2016; Khan et al., 2016). In all cases, the CSP term's significance is independent of including an interaction term. However, in some cases, the impact of CSP is stronger in environmental sensitive industries.

Finally, we check for the robustness with respect to the ESG rating provider by using environmental and social category scores from Refinitiv instead of Asset4. Most categories of Refinitiv can be mapped to a variable of Asset4, except for diversity aspects that are an own category in the As- 
set4 framework while being included in the workforce category of Refinitiv. According to the estimation results in Tables 17 to 20 based on Refinitiv, the main analysis is largely confirmed in terms of significance of effects and most important impact drivers. This implies that the most distinct effect in North America is observed with Environmental innovation.

\section{Conclusion}

The primary purpose of this paper is to provide a consistent analysis of the impact of CSP on systematic firm risk in an international sample comprising 3800 companies. This paper extends the three recent studies of Albuquerque et al. (2018), Sassen et al. (2016), and Utz (2018) on the relationship between CSP and systematic, respectively idiosyncratic firm risk. Our study contributes to the existing literature in several ways as it is the first analysis in the context of systematic risk based on the transparent CSP measures of Asset4 and also the first to identify single CSP drivers in an international sample based on the instrumental variable approach and various measures for systematic risk (by the CAPM, the five-factor asset pricing model of Fama and French, and the international CAPM).

Our results show that high CSP tends to be consistent with low systematic risk in North America, Europe, Asia-Pacific, and Japan. Thus, risk mitigation applies across all of these regions. We find the impact of overall CSP performance to be most influential for firms located in North America, and in descending order weaker but still significant in Europe, Asia-Pacific, 
and Japan. Generally, all CSP components show an impact on systematic risk albeit to a varying extent. The impact is mainly driven by product responsibility aspects in North America and Japan, and employees in Europe. Environmental innovation is the main driver in Asia-Pacific. Effects of other CSP categories are less dominant.

When comparing our results to previous literature, we can confirm the first empirical evidence of Albuquerque et al. (2018) for the U.S. With our improved methodological approach, we also find evidence for the workforce measure in Europe while Sassen et al. (2016) do not. For systematic risk, the risk mitigation view holds in each of the four regions, which is only partially consistent with Utz (2018), who finds evidence of the over-investment hypothesis in Asia-Pacific in the context of idiosyncratic risk. Our results imply that high CSP firms face reduced systematic risk but also may lose stock market performance due to their lower participation in the overall positive market trend in the long run.

Furthermore, our findings reveal several implications for capital allocation, investment valuation, and portfolio selection. As firm beta is a crucial determinant for their cost of equity (Albuquerque et al., 2018), firms can lower it through investing in CSP. Also, a lower cost of equity results in a better valuation of investment opportunities as future cash flows can be discounted at a lower rate. The overall portfolio selection considers the total risk of a portfolio, within which systematic risk is a substantial part because, unlike idiosyncratic risk, it cannot be eliminated through diversification. Thus, 
investors may identify low risk stocks by considering certain aspects of CSP.

10

11

12

13

14

15

16

17

18

19

20

21

22

24

25

26

27

28

29

30

31

32

33

34

35

36

37

38

39

40

41

42

43

44

45

46

47

48

49

50

51

52

53

54

55

56

57

58

59

60 
Albuquerque, R., Koskinen, Y., Zhang, C., 2018. Corporate social responsibility and firm risk: Theory and empirical evidence. Management Science.

Attig, N., El Ghoul, S., Guedhami, O., Suh, J., 2013. Corporate social responsibility and credit ratings. Journal of Business Ethics 117 (4), 679-694.

Aupperle, K., Carroll, A., Hatfield, J. D., 1985. An empirical examination of the relationship between corporate social responsibility and profitability. Academy of Management Journal 28 (2), 446-463.

Bauer, R., Hann, D., 2010. Corporate environmental management and credit risk. Working Paper. Maastricht University, European Centre for Corporate Engagement (ECCE).

Beaver, W., Kettler, P., Scholes, M., 1970. The association between market determined and accounting determined risk measures. The Accounting Review 45 (4), 654-682.

Botero, J. C., Djankov, S., Porta, R. L., Lopez-de Silanes, F., Shleifer, A., 2004. The regulation of labor. Quarterly Journal of Economics 119 (4), 1339-1382.

Brammer, S., Millington, A., 2008. Does it pay to be different? An analysis of the relationship between corporate social and financial performance. Strategic Management Journal 29 (12), 1325-1343.

Brandt, M. W., Brav, A., Graham, J. R., Kumar, A., 2010. The idiosyn- 
cratic volatility puzzle: Time trend or speculative episodes? The Review of Financial Studies 23 (2), 863-899.

Campbell, J. Y., Hilscher, J., Szilagyi, J., 2008. In search of distress risk. Journal of Finance 63 (6), 2899-2939.

Chapple, W., Moon, J., 2005. Corporate social responsibility (csr) in asia: A seven-country study of csr web site reporting. Business \& society 44 (4), 415-441.

Chatterji, A., Levine, D., 2006. Breaking down the wall of codes: Evaluating non-financial performance measurement. California Management Review 48 (2), 29-51.

Cornell, B., Shapiro, A. C., 1987. Corporate stakeholders and corporate finance. Financial Management, 5-14.

DeAngelo, H., DeAngelo, L., Stulz, R. M., 2006. Dividend policy and the earned/contributed capital mix: a test of the life-cycle theory. Journal of Financial Economics 81 (2), 227-254.

Dhaliwal, D. S., Li, O. Z., Tsang, A., Yang, Y. G., 2011. Voluntary nonfinancial disclosure and the cost of equity capital: The initiation of corporate social responsibility reporting. The Accounting Review 86 (1), 59-100.

Dimson, E., Karakaş, O., Li, X., 2015. Active ownership. Review of Financial Studies 28 (12), 3225-3268. 
Dorfleitner, G., Grebler, J., Utz, S., 2020. The impact of corporate social and environmental performance on credit rating prediction: North America versus Europe. Journal of Risk 22 (6), 1-33.

Dorfleitner, G., Utz, S., Wimmer, M., 2018. Patience pays off-corporate social responsibility and long-term stock returns. Journal of Sustainable Finance \& Investment 8 (2), 132-157.

El Ghoul, S., Guedhami, O., Kim, Y., 2017. Country-level institutions, firm value, and the role of corporate social responsibility initiatives. Journal of International Business Studies 48 (3), 360-385.

El Ghoul, S., Guedhami, O., Kwok, C. C., Mishra, D. R., 2011. Does corporate social responsibility affect the cost of capital? Journal of Banking \& Finance 35 (9), 2388-2406.

Fama, E. F., French, K. R., 2012. Size, value, and momentum in international stock returns. Journal of Financial Economics 105 (3), 457-472.

Fama, E. F., French, K. R., 2015. A five-factor asset pricing model. Journal of financial economics 116 (1), 1-22.

Flammer, C., 2015. Does corporate social responsibility lead to superior financial performance? A regression discontinuity approach. Management Science 61 (11), 2549-2568.

Fons, J. S., 1994. Using default rates to model the term structure of credit risk. Financial Analysts Journal 50 (5), 25-32. 
Friewald, N., Wagner, C., Zechner, J., 2014. The cross-section of credit risk premia and equity returns. Journal of Finance 69 (6), 2419-2469.

Goodden, R. L., 2009. Lawsuit!: Reducing the Risk of Product Liability for Manufacturers. John Wiley \& Sons.

Goss, A., Roberts, G. S., 2011. The impact of corporate social responsibility on the cost of bank loans. Journal of Banking \& Finance 35 (7), 1794-1810.

Hamada, R. S., 1972. The effect of the firm's capital structure on the systematic risk of common stocks. The journal of finance 27 (2), 435 - 452 .

Hoberg, G., Prabhala, N. R., 2009. Disappearing dividends, catering, and risk. Review of Financial Studies 22 (1), 79-116.

Hofstede, G., 2001. Culture's consequences: Comparing values, behaviors, institutions and organizations across nations. Sage publications.

Hofstede, G., Hofstede, G. J., Minkov, M., 2010. Cultures and organizations, software of the mind. Intercultural cooperation and its importance for survival. McGraw-Hill.

Ioannou, I., Serafeim, G., 2012. What drives corporate social performance? The role of nation-level institutions. Journal of International Business Studies 43 (9), 834-864.

Jiraporn, P., Jiraporn, N., Boeprasert, A., Chang, K., 2014. Does corpo- 
rate social responsibility (CSR) improve credit ratings? Evidence from geographic identification. Financial Management 43 (3), 505-531.

Kang, C., Germann, F., Grewal, R., 2016. Washing away your sins? Corporate social responsibility, corporate social irresponsibility, and firm performance. Journal of Marketing 80 (2), 59-79.

Khan, M., Serafeim, G., Yoon, A., 2016. Corporate sustainability: First evidence on materiality. The Accounting Review 91 (6), 1697-1724.

Kim, Y., Li, H., Li, S., 2014. Corporate social responsibility and stock price crash risk. Journal of Banking \& Finance 43, 1-13.

La Porta, R., Lopez-de Silanes, F., Shleifer, A., 2006. What works in securities laws? Journal of Finance 61 (1), 1-32.

Lee, D. D., Faff, R. W., 2009. Corporate sustainability performance and idiosyncratic risk: A global perspective. Financial Review 44 (2), 213-237.

Lee, D. D., Faff, R. W., Langfield-Smith, K., 2009. Revisiting the vexing question: does superior corporate social performance lead to improved financial performance? Australian Journal of Management 34 (1), 21-49.

Lev, B., 1974. On the association between operating leverage and risk. Journal of financial and quantitative analysis 9 (4), 627-641.

Lins, K. V., Servaes, H., Tamayo, A., 2017. Social capital, trust, and firm per- 
formance: The value of corporate social responsibility during the financial crisis. Journal of Finance 72 (4), 1785-1824.

Lintner, J., 1975. The valuation of risk assets and the selection of risky investments in stock portfolios and capital budgets. In: Stochastic optimization models in finance. Elsevier, pp. 131-155.

Luo, X., Wang, H., Raithel, S., Zheng, Q., 2015. Corporate social performance, analyst stock recommendations, and firm future returns. Strategic Management Journal 36 (1), 123-136, doi: 10.1002/smj.2219.

Margolis, J. D., Elfenbein, H. A., Walsh, J. P., 2007. Does it pay to be good? A meta-analysis and redirection of research on the relationship between corporate social and financial performance. Ann Arbor 1001, 48109-1234.

McAlister, L., Srinivasan, R., Kim, M., 2007. Advertising, research and development, and systematic risk of the firm. Journal of Marketing 71 (1), $35-48$.

McWilliams, A., Siegel, D., 2001. Corporate social responsibility: A theory of the firm perspective. Academy of Management Review 26 (1), 117-127.

Melicher, R. W., Rush, D. F., 1973. The performance of conglomerate firms: Recent risk and return experience. Journal of Finance 28 (2), 381-388.

Merton, R. C., 1974. On the pricing of corporate debt: The risk structure of interest rates. Journal of Finance 29 (2), 449-470. 
Mossin, J., 1966. Equilibrium in a capital asset market. Econometrica, 768783.

Newey, W. K., West, K. D., 1986. A simple, positive semi-definite, heteroskedasticity and autocorrelationconsistent covariance matrix. Econometrica 55 (3), 703-708.

Novy-Marx, R., 2010. Operating leverage. Review of Finance 15 (1), 103-134.

Orlitzky, M., 2008. Corporate social performance and financial performance: A research synthesis. In: Crane, A., McWilliams, A., Matten, D., Moon, J., Siegel, D. S. (Eds.), The Oxford Handbook of Corporate Social Responsibility. Oxford University Press, pp. 113-134.

Orlitzky, M., Schmidt, F. L., Rynes, S. L., 2003. Corporate social and financial performance: A meta-analysis. zation Studies 24 (3), 403-441.

Palazzo, B., 2012. Cash holdings, risk, and expected returns. Journal of Financial Economics 104 (1), 162-185.

Pástor, L., Pietro, V., 2003. Stock valuation and learning about profitability. Journal of Finance 58 (5), 1749-1789.

Rampini, A. A., Viswanathan, S., 2013. Collateral and capital structure. Journal of Financial Economics 109 (2), 466-492.

Sassen, R., Hinze, A.-K., Hardeck, I., 2016. Impact of esg factors on firm risk in europe. Journal of Business Economics 86 (8), 867-904. 
Servaes, H., Tamayo, A., 2013. The impact of corporate social responsibility on firm value: The role of customer awareness. Management Science 59 (5), 1045-1061.

Sharpe, W. F., 1964. Capital asset prices: A theory of market equilibrium under conditions of risk. Journal of Finance 19 (3), 425-442.

Stellner, C., Klein, C., Zwergel, B., 2015. Corporate social responsibility and Eurozone corporate bonds: The moderating role of country sustainability. Journal of Banking \& Finance 59, 538-549.

Turban, D. B., Greening, D. W., 1997. Corporate social performance and organizational attractiveness to prospective employees. Academy of Management Journal 40 (3), 658-672.

Utz, S., 2018. Over-investment or risk mitigation? Corporate social responsibility in Asia-Pacific, Europe, Japan, and the United States. Review of Financial Economics 36 (2), 167-193.

Von Arx, U., Ziegler, A., 2014. The effect of corporate social responsibility on stock performance: New evidence for the USA and Europe. Quantitative Finance 14 (6), 977-991.

Whitley, R., 1999. Divergent capitalisms: The social structuring and change of business systems. OUP Oxford. 


\section{Table 1: Country structure of regional panels}

This table presents the mapping of countries to the regions of North America, Europe, Japan, and Asia-Pacific as well as the respective numbers of observations. We analyze the impact of CSP on credit risk based on the three regional panels and consider country fixed effects among the control variables.

\begin{tabular}{llrr}
\hline Region & Countries & \#Observations & \#Firms \\
\hline North America & Canada, United States of America & 8327 & 2029 \\
Europe & Belgium, Switzerland, Germany, Denmark, Spain, Finland, France, & & \\
& Greece, Great Britain, Italy, Netherlands, Norway, Portugal, & 5393 & 824 \\
& Sweden & 2219 & 291 \\
Japan & Japan & 2787 & 656 \\
Asia-Pacific & Australia, Hong Kong, India, Malaysia, New Zealand, & 18726 & 3800 \\
Total & Singapore, Taiwan & & \\
\hline
\end{tabular}




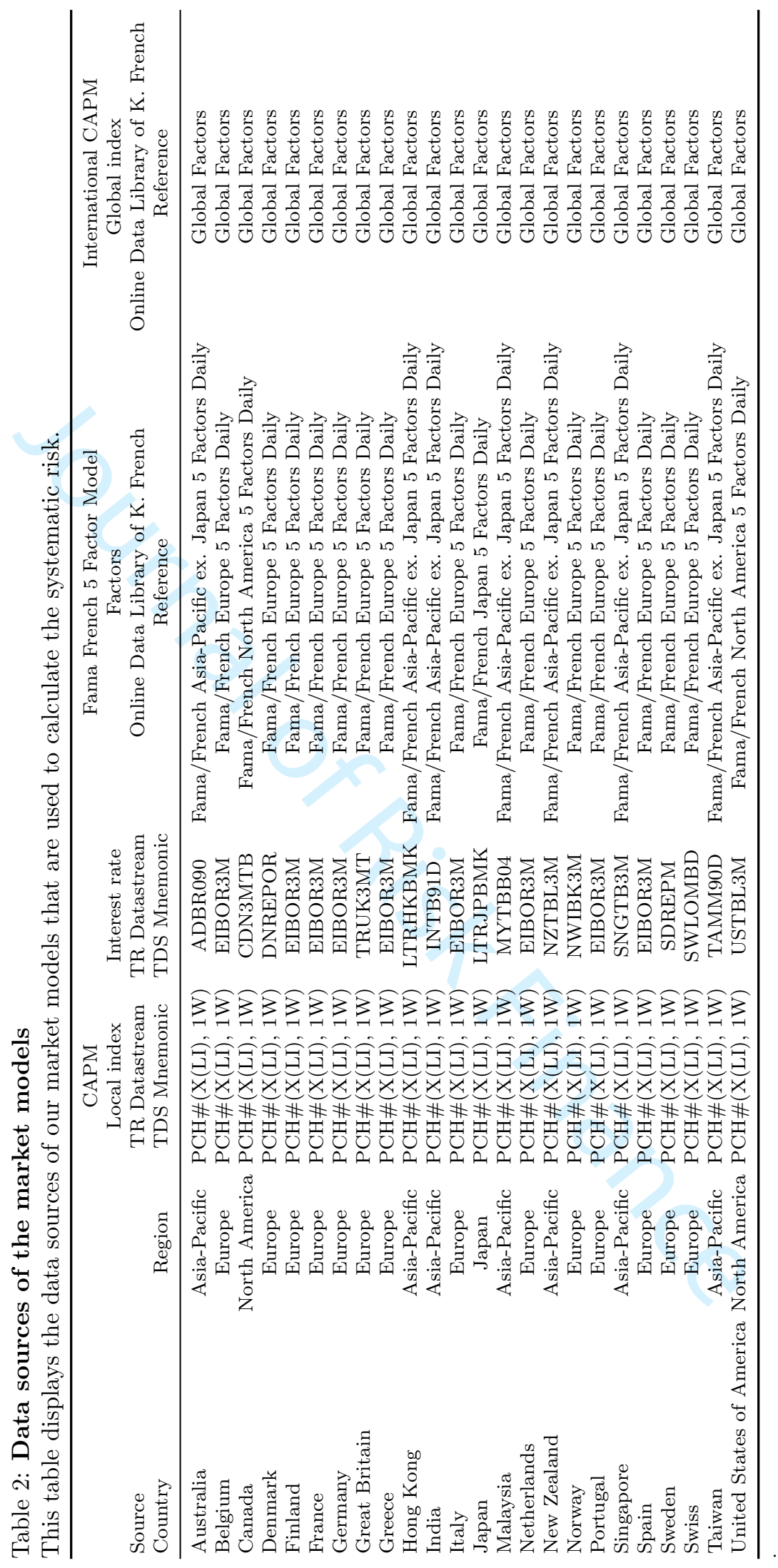


Table 3: Distribution of firms' alpha and market beta coefficients

This table reports descriptive statistics for the distribution of estimated yearly firm CAPM alphas and market betas based on weekly data covering the period from 2003 till 2018 per region. The betas are our proxy for systematic risk and are hence included as the dependent variable in the second stage of our 2SLS estimation. Provided p-Values are based on the Newey-West estimator.

\begin{tabular}{|c|c|c|c|c|c|c|c|c|c|c|}
\hline & \multicolumn{4}{|c|}{ Distribution of Coefficient } & \multicolumn{4}{|c|}{ Distribution of p-Values } & \multirow{2}{*}{ \#Obs. } & \multirow{2}{*}{$\begin{array}{c}\text { thereof } \% \text {-share of } \\
\text { p-Value }<5 \%\end{array}$} \\
\hline & $25 \%-\mathrm{Qu}$. & $\overline{5 \%} \mathrm{-Qu}$ & Mean & SD & $25 \%-\mathrm{Qu}$ & $5 \%-\mathrm{Qu}$ & Mean & SD & & \\
\hline \multicolumn{11}{|c|}{ North America } \\
\hline$\widehat{\alpha}(\%)$ & -0.209 & 0.402 & 0.089 & 0.558 & 0.216 & 0.729 & 0.476 & 0.294 & 8327 & 7 \\
\hline$\widehat{\beta}$ & 0.732 & 1.411 & 1.101 & 0.517 & 0.000 & 0.003 & 0.032 & 0.115 & 8327 & 90 \\
\hline \multicolumn{11}{|l|}{ Europe } \\
\hline$\widehat{\alpha}(\%)$ & -0.150 & 0.471 & 0.145 & 0.558 & 0.186 & 0.707 & 0.451 & 0.296 & 5393 & 9 \\
\hline$\widehat{\beta}$ & 0.647 & 1.196 & 0.929 & 0.424 & 0.000 & 0.004 & 0.042 & 0.138 & 5393 & 87 \\
\hline \multicolumn{11}{|l|}{ Japan } \\
\hline$\widehat{\alpha}(\%)$ & -0.156 & 0.404 & 0.133 & 0.462 & 0.265 & 0.764 & 0.513 & 0.291 & 2219 & 5 \\
\hline$\widehat{\beta}$ & 0.767 & 1.271 & 1.014 & 0.367 & 0.000 & 0.000 & 0.012 & 0.074 & 2219 & 96 \\
\hline \multicolumn{11}{|l|}{ Asia-Pacific } \\
\hline$\widehat{\alpha}(\%)$ & -0.312 & 0.419 & 0.029 & 0.678 & 0.202 & 0.719 & 0.461 & 0.296 & 2787 & 8 \\
\hline$\widehat{\beta}$ & 0.607 & 1.286 & 0.953 & 0.522 & 0.000 & 0.027 & 0.076 & 0.187 & 2787 & 79 \\
\hline
\end{tabular}


Table 4: Details on CSP variables

This table presents detailed information about the CSP variables that we used as provided 
The society/community category measures a company's management commitment and effectiveness towards maintaining the company's reputation within the general community (local, national, and global). It reflects a company's capacity to maintain its license to operate by being a good citizen (donations of cash, goods or staff time, etc.), protecting public health (avoidance of industrial accidents, etc.), and respecting business ethics (avoiding bribery and corruption, etc.). - Source: Thomson Reuters Datastream; Mnemonic SOCO.

etc.). Source: Thomson Reuters Datastream; Mnemonic SOCO.

\begin{tabular}{ll}
\hline Human rights & The society/human rights category measures a company's management commit- \\
ment and effectiveness towards respecting the fundamental human rights con- & ventions. It reflects a company's capacity to maintain its license to operate by \\
& guaranteeing the freedom of association and excluding child, forced or compul- \\
& sory labour. - Source: Thomson Reuters Datastream; Mnemonic SOHR. \\
\hline Diversity & The workforce/diversity and opportunity category measures a company's man- \\
& agement commitment and effectiveness towards maintaining diversity and equal \\
& opportunities in its workforce. It reflects a company's capacity to increase its \\
& workforce loyalty and productivity by promoting a sufficient life-work balance, a \\
& family-friendly environment, and equal opportunities regardless of gender, age, \\
& ethnicity, religion or sexual orientation. - Source: Thomson Reuters Datastream; \\
Mnemonic SODO.
\end{tabular}


This category includes employment quality, health/safety, and training and development. The workforce/employment quality category measures both a company's management commitment and its effectiveness towards providing highquality employment benefits and job conditions. It reflects a company's capacity to increase its workforce loyalty and productivity by distributing rewarding and fair employment benefits, and by focusing on long-term employment growth and stability by promoting from within, avoiding lay-offs, and maintaining relations with trade unions. The workforce/health \& safety category measures a company's management commitment and effectiveness towards providing a healthy and safe workplace. It reflects a company's capacity to increase its workforce loyalty and productivity by integrating into its day-to-day operations a concern for the physical and mental health, well-being, and stress level of all employees. The workforce/training and development category measures a company's management commitment and effectiveness towards providing training and development (education) for its workforce. It reflects a company's capacity to increase its intellectual capital, workforce loyalty, and productivity by developing the workforce's skills, competencies, employability, and careers in an entrepreneurial environment. - Source: Thomson Reuters Datastream; Mnemonics SOEQ, SOHS, and SOTD. 

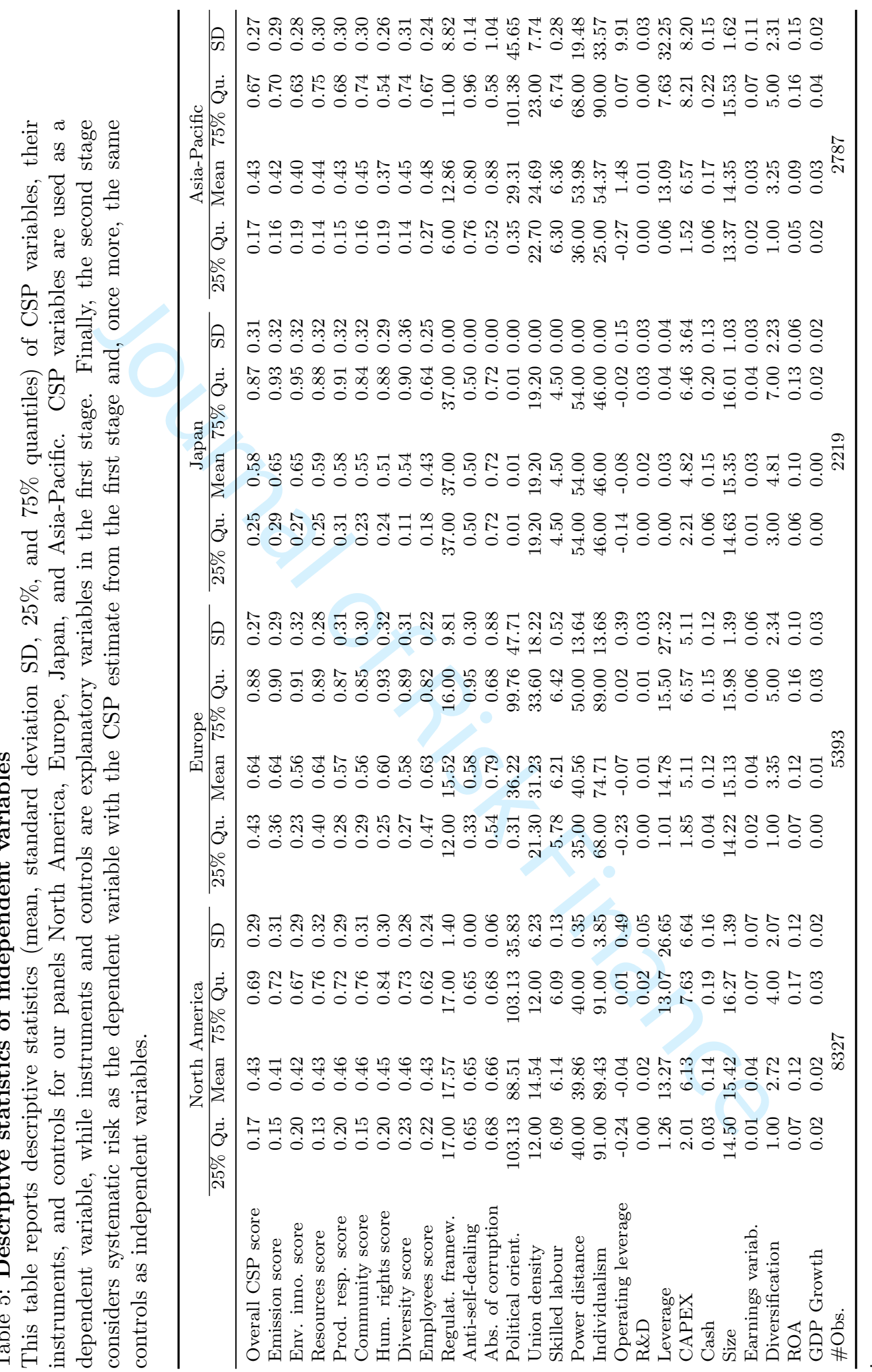
Table 6: Details on employed instruments

This table gives an overview of the instruments that we used in the first stage of our 2SLS estimations based on Jiraporn et al. (2014) and Ioannou and Serafeim (2012). 
Table 7: Details on control variables

This table presents details on the used control variables provided by Thomson Reuters Datastream.

\begin{tabular}{|c|c|}
\hline Variable & Definition \\
\hline Operating leverage & $\begin{array}{l}\text { Growth of operating expenses divided by the increase in total sales. Both } \\
\text { operating expense and total sales are predicted based on the geometric growth } \\
\text { rate. - Source: Thomson Reuters Datastream; Mnemonics WC01249, DWSL. }\end{array}$ \\
\hline $\mathrm{R} \& \mathrm{D}$ & $\begin{array}{l}\text { Sum of all direct and indirect costs for the purpose of research, creation } \\
\text { and development of new processes, techniques, applications, and products for } \\
\text { commercial use divided by total assets. Missing values are replaced by zero. } \\
\text { - Source: Thomson Reuters Datastream; Mnemonics WC01201, WC02999. }\end{array}$ \\
\hline Leverage & $\begin{array}{l}\text { Long-term debt to total assets ratio. - Source: Thomson Reuters Datastream; } \\
\text { Mnemonics WC08216, WC02999. }\end{array}$ \\
\hline CAPEX & $\begin{array}{l}\text { Capital expenditures divided by total assets. - Source: Thomson Reuters } \\
\text { Datastream; Mnemonic WC08416. }\end{array}$ \\
\hline Cash & $\begin{array}{l}\text { Sum of cash and short-term investments divided by total assets. - Source: } \\
\text { Thomson Reuters Datastream; Mnemonics WC02001, WC02999. }\end{array}$ \\
\hline Size & $\begin{array}{l}\text { Logarithm of market capitalization in USD. - Source: Thomson Reuters } \\
\text { Datastream; Mnemonic WC07210. }\end{array}$ \\
\hline Earnings variab. & $\begin{array}{l}\text { Standard deviation of net income before extra items/preferred dividends of } \\
\text { the previous five years over total assets. - Source: Thomson Reuters Datas- } \\
\text { tream; Mnemonics WC } 01551 \text {, WC02999. }\end{array}$ \\
\hline Diversification & $\begin{array}{l}\text { The number of four-digit ISIC codes. - Source: Thomson Reuters Datastream; } \\
\text { Mnemonics WC07021-8. }\end{array}$ \\
\hline ROA & $\begin{array}{l}\text { Earnings before interest, taxes, and depreciation over total assets. - Source: } \\
\text { Thomson Reuters Datastream; Mnemonics WC18198, WC02999. }\end{array}$ \\
\hline GDP growth & $\begin{array}{l}\text { The annual growth rate of the gross domestic product. - Source: Thomson } \\
\text { Reuters Datastream; Mnemonic GDP..D (in combination with the two letter } \\
\text { country code). }\end{array}$ \\
\hline
\end{tabular}


Table 8: Overview on industry classes in the sample

This table reports on the number of observations per industry class, according to Fama and French, per region. We include firm fixed effects among the controls in both stages of our 2SLS estimation.

\begin{tabular}{lrrrr}
\hline Industry Class & North America & Europe & Japan & Asia-Pacific \\
\hline Consumer NonDurables & 461 & 536 & 164 & 160 \\
Consumer Durables - Cars, TVs, Furniture, Household & & & & \\
Appliances & 220 & 131 & 126 & 59 \\
Manufacturing - Machinery, Trucks, Planes, Chemicals, & & & & \\
Off Furn, Paper & 1105 & 933 & 595 & 324 \\
Oil, Gas, and Coal Extraction and Products & 720 & 253 & 41 & 201 \\
Business Equipment - Computers, Software, and & & & & \\
Electronic Equipment & 1347 & 437 & 355 & 348 \\
Telephone and Television Transmission & 236 & 227 & 52 & 115 \\
Wholesale, Retail, and Some Services (Laundries, Repair) & 798 & 644 & 206 & 275 \\
Healthcare, Medical Equipment, and Drugs & 681 & 304 & 97 & 90 \\
Utilities & 532 & 257 & 72 & 125 \\
Other & 2227 & 1671 & 511 & 1090 \\
Total & 8327 & 5393 & 2219 & 2787 \\
\hline
\end{tabular}




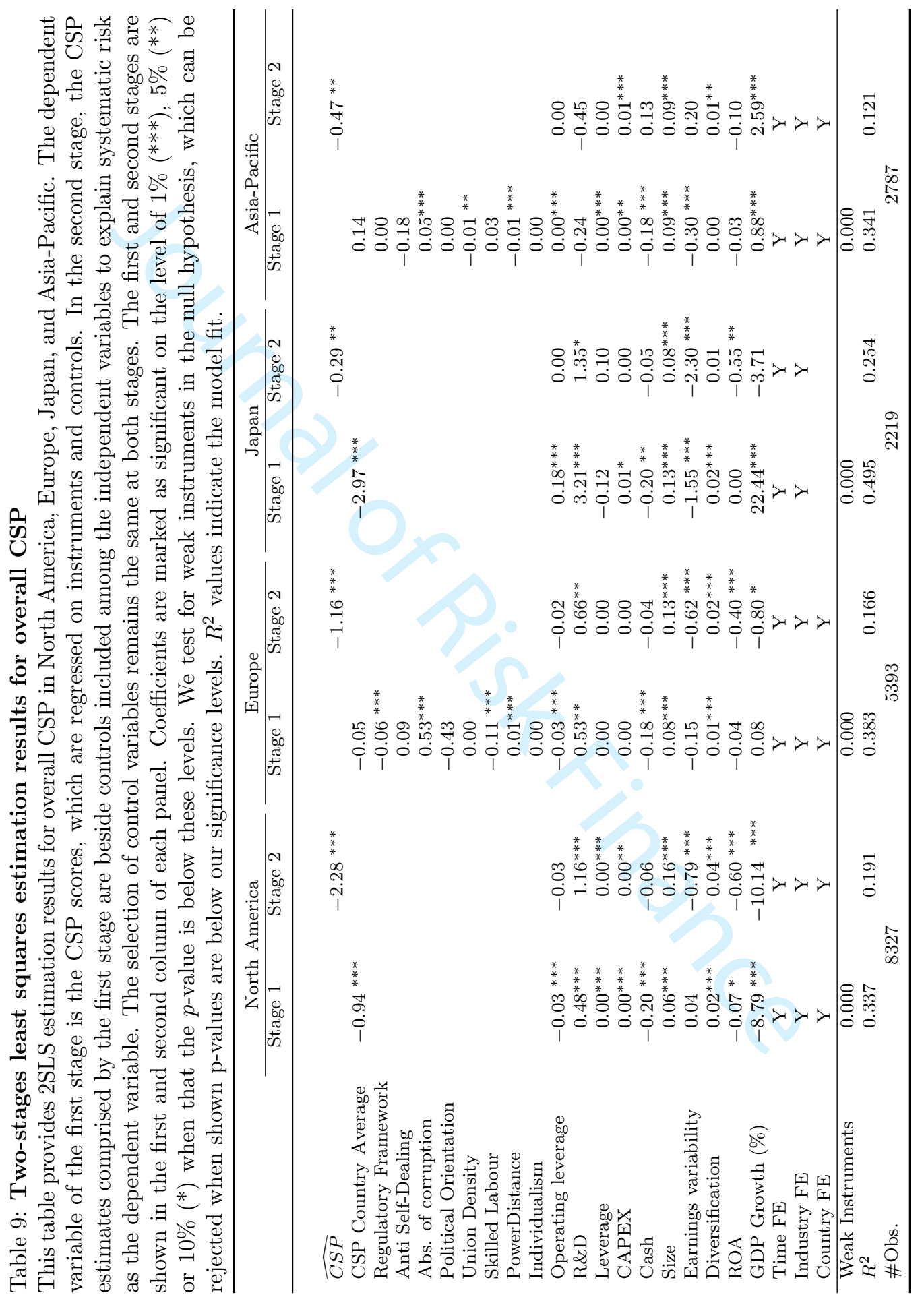




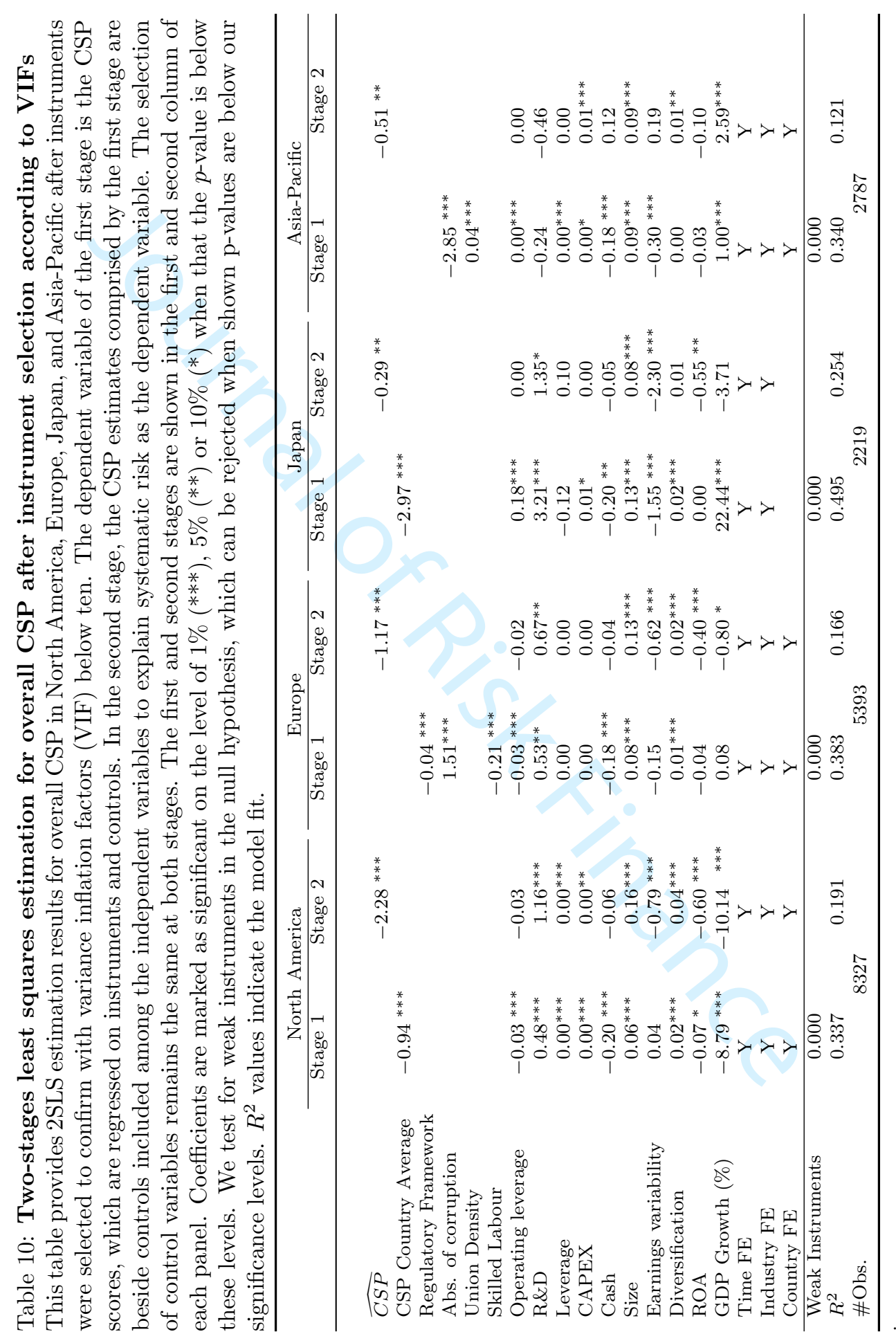




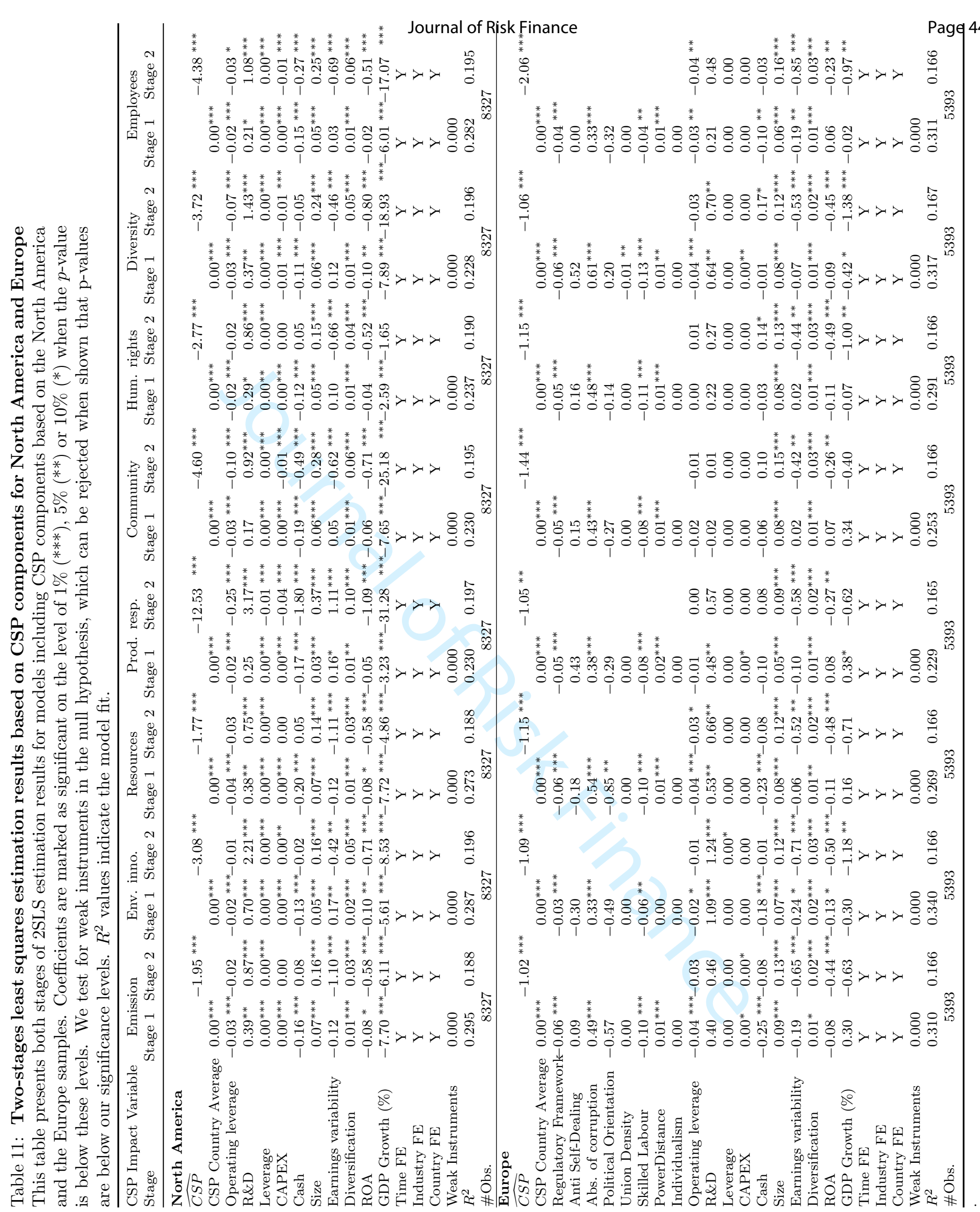




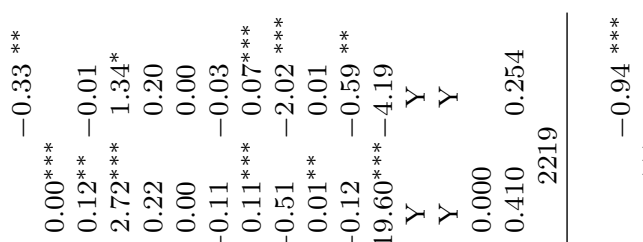
*

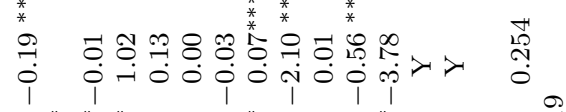

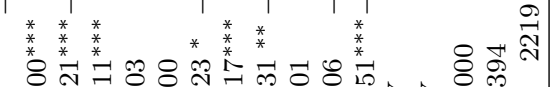

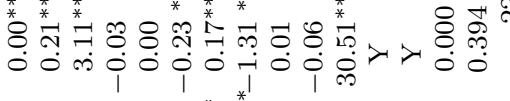
* * * * * * * * * * * * * * *

*

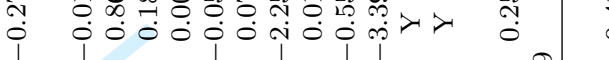

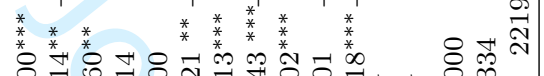

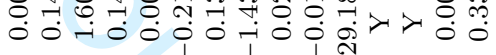

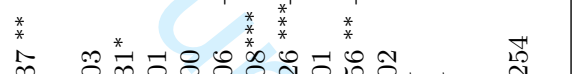
花

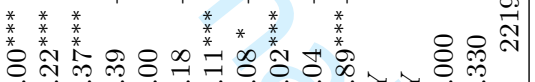

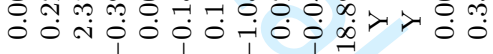
*

.0 be

U

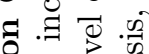

0 告过

क्ष

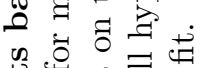

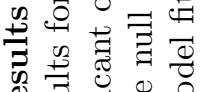

⿹弋口

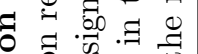

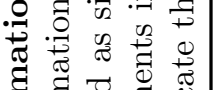

苟

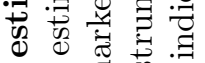

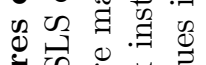

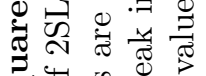

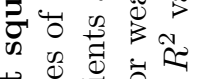

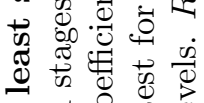

o $\frac{1}{1}$ 过

$\infty_{0}^{\infty} \dot{0} \dot{8}$

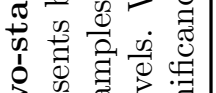

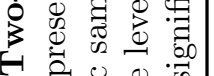

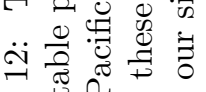

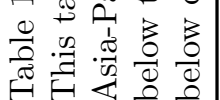

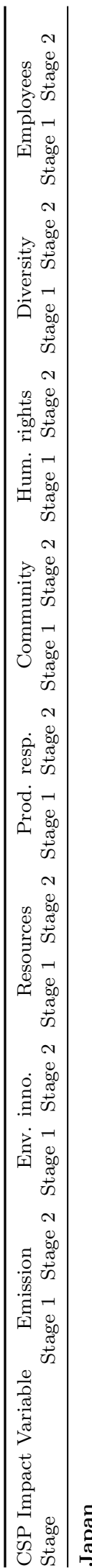

*

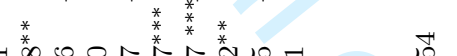

i

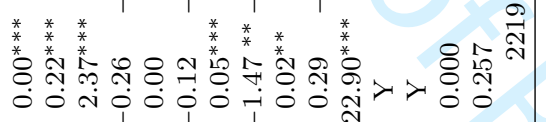

*

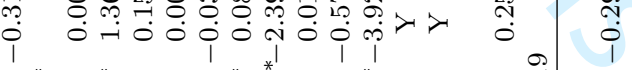

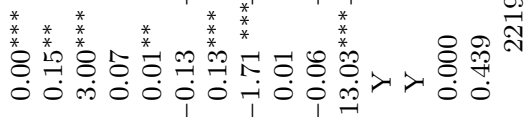

䒹

i onoojonomir

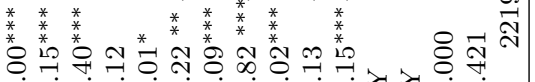

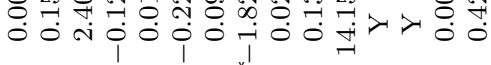

*

F.

1 i

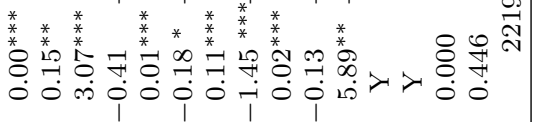

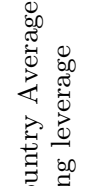

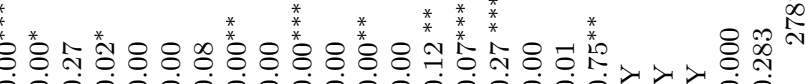

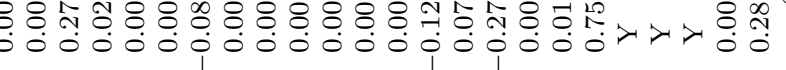

$\stackrel{*}{*}$

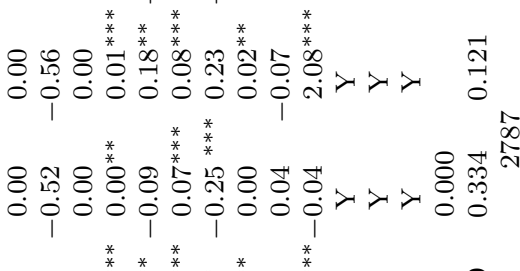

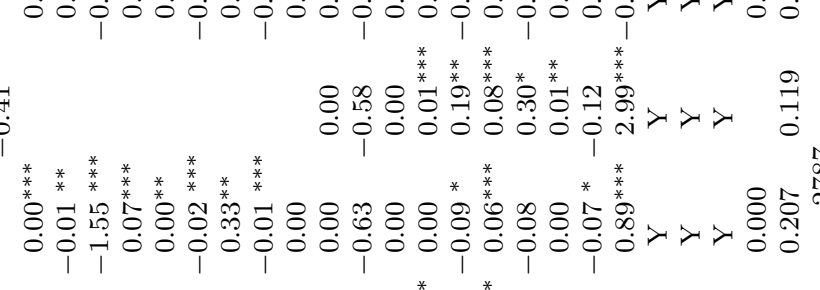

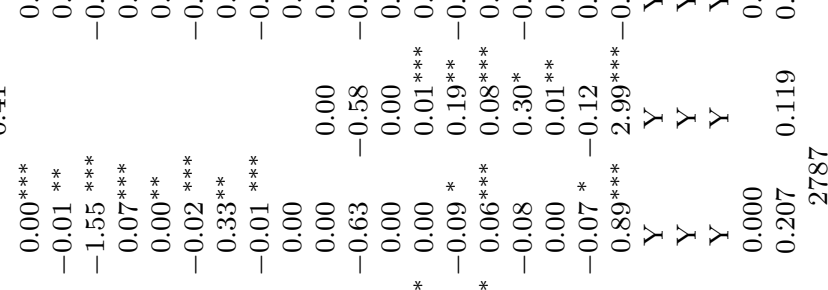

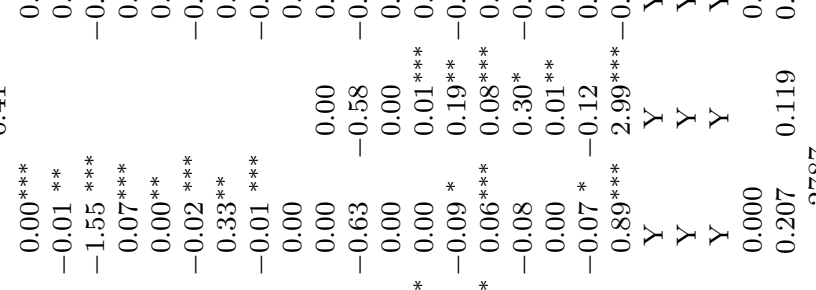
:

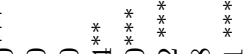

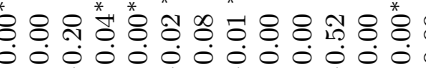

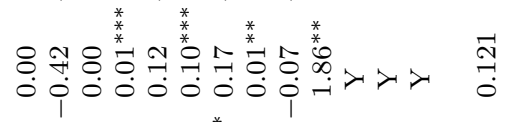

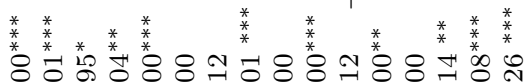

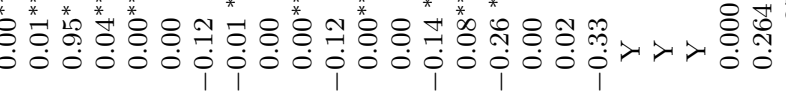

$\stackrel{\substack{n \\ 0}}{1}$

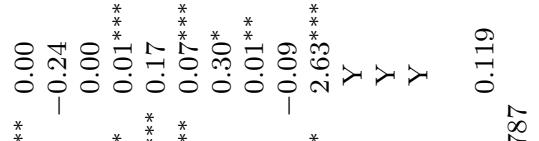

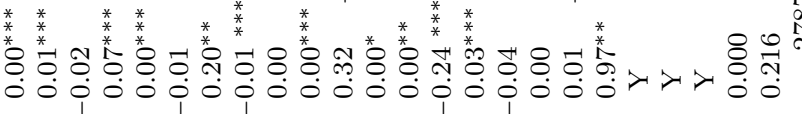

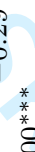

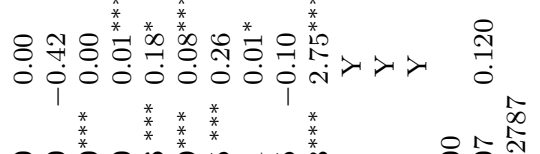

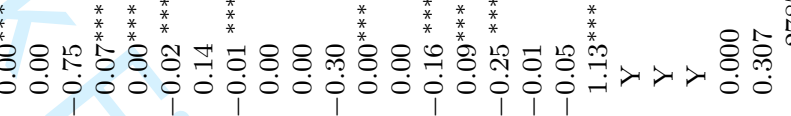

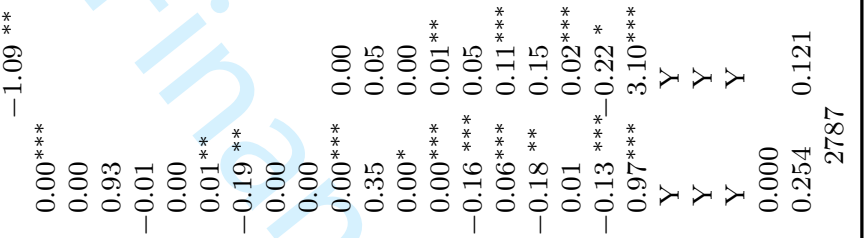

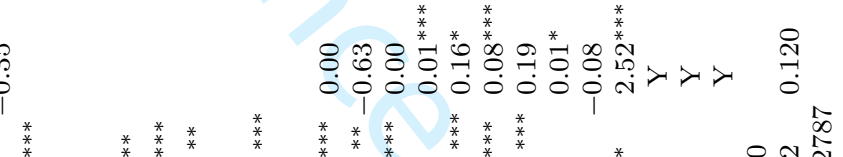

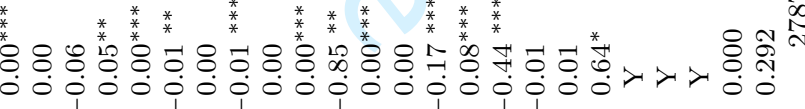

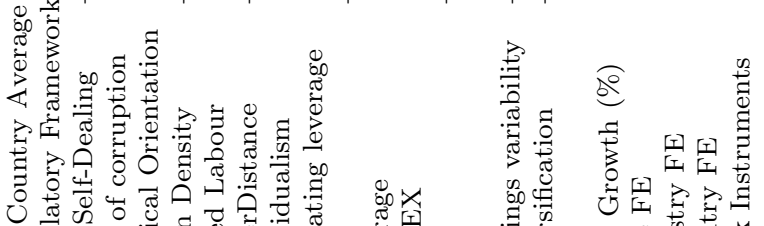

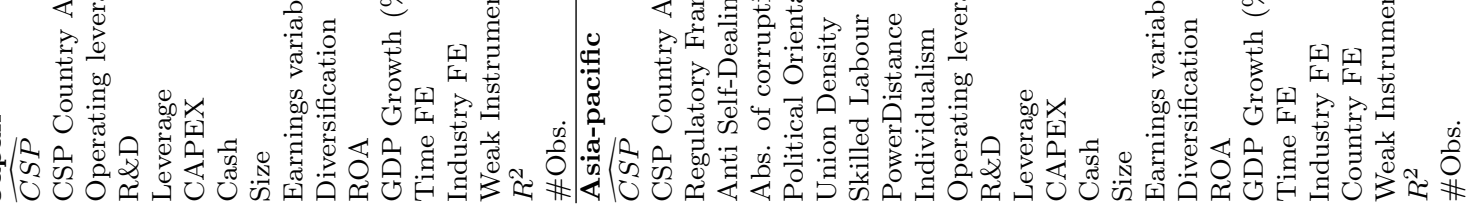




\section{Table 13: Two-stages least squares estimation results of non-linear model}

This table reports on 2SLS regression results for the CSP estimate and the squared CSP estimate of our non-linear model concerning both overall CSP and its components in the regions of North America, Europe, Japan, and Asia-Pacific. Coefficients are marked as significant on the level of $1 \%(* * *), 5 \%(* *)$ or $10 \%\left(^{*}\right)$ when the $p$-value is below these levels. $R^{2}$ values measure the fit of each model. The panel size is provided in terms of the number of observations.

\begin{tabular}{|c|c|c|c|c|c|c|c|c|c|}
\hline \multicolumn{2}{|c|}{ Overall CSP } & Emission & Env. inno. & Resources & Prod. resp. & Comm. & Hum. rights & Diversity & Employees \\
\hline \multicolumn{10}{|c|}{ North America } \\
\hline$\widehat{C S P}$ & $0.02^{* * *}$ & $0.06^{* * *}$ & $-0.36^{* * *}$ & $0.30^{* * *}$ & $-6.35^{* * *}$ & $-0.65 * * *$ & $0.71^{* * *}$ & $-0.22^{* * *}$ & $0.28^{* * *}$ \\
\hline$\widehat{C S P}^{2}$ & $-2.26^{* * *}$ & $-2.06^{* * *}$ & $-2.49^{* * *}$ & $-2.11^{* * *}$ & $-3.39 * * *$ & $-2.73^{* * *}$ & $-2.80^{* * *}$ & $-2.84 * * *$ & $-3.58^{* * *}$ \\
\hline$R^{2}$ & 0.21 & 0.21 & 0.21 & 0.21 & 0.22 & 0.22 & 0.21 & 0.22 & 0.22 \\
\hline \multicolumn{10}{|c|}{ Europe } \\
\hline$\widehat{C S P}$ & $-1.31^{* * *}$ & $-1.43^{* * *}$ & $-1.19^{* * *}$ & $-1.16^{* * *}$ & $-1.12^{* * *}$ & $-2.19^{* * *}$ & $-1.28^{* * *}$ & $-0.93^{* * *}$ & $-2.22^{* * *}$ \\
\hline$\widehat{C S P}^{2}$ & $0.10^{* * *}$ & $0.29^{* * *}$ & $0.08^{* * *}$ & $0.00^{* * *}$ & $0.06^{* * *}$ & $0.53^{* * *}$ & $0.09^{* * *}$ & $-0.10^{* * *}$ & $0.09^{* * *}$ \\
\hline$R^{2}$ & 0.17 & 0.17 & 0.17 & 0.17 & 0.17 & 0.17 & 0.17 & 0.17 & 0.17 \\
\hline $\begin{array}{l}\text { \#Obs. } \\
\text { Japan }\end{array}$ & 5393 & 5393 & 5393 & 5393 & 5393 & 5393 & 5393 & 5393 & 5393 \\
\hline$\widehat{C S P}$ & $-0.02^{* * *}$ & $-0.13^{* * *}$ & $-0.01^{* * *}$ & $0.02^{* * *}$ & $-0.48^{* * *}$ & $-0.05 * * *$ & $-0.14^{* * *}$ & $-0.14^{* * *}$ & $0.15^{* * *}$ \\
\hline$\widehat{C S P}^{2}$ & $-0.19^{* * *}$ & $-0.16^{* * *}$ & $-0.27^{* * *}$ & $-0.23^{* * *}$ & $-0.14^{* * *}$ & $-0.22 * * *$ & $-0.11^{* * *}$ & $-0.04 * * *$ & $-0.46^{* * *}$ \\
\hline$R^{2}$ & 0.25 & 0.25 & 0.26 & 0.26 & 0.25 & 0.25 & 0.25 & 0.25 & 0.26 \\
\hline \#Obs. & 2219 & 2219 & 2219 & 2219 & 2219 & 2219 & 2219 & 2219 & 2219 \\
\hline \multicolumn{10}{|c|}{ Asia-Pacific } \\
\hline$\widehat{C S P}$ & $0.42^{* * *}$ & $0.43^{* * *}$ & $0.06^{* * *}$ & $0.78^{* * *}$ & $0.17^{* * *}$ & $0.28^{* * *}$ & $1.13^{* * *}$ & $-0.49^{* * *}$ & $0.80^{* * *}$ \\
\hline$\widehat{C S P}^{2}$ & $-0.95^{* * *}$ & $-0.85^{* * *}$ & $-1.10^{* * *}$ & $-1.10^{* * *}$ & $-0.46^{* * *}$ & $-1.00 * * *$ & $-1.60^{* * *}$ & $0.06^{* * *}$ & $-1.49^{* * *}$ \\
\hline$R^{2}$ & 0.12 & 0.12 & 0.12 & 0.12 & 0.12 & 0.12 & 0.12 & 0.12 & 0.13 \\
\hline \#Obs. & 2787 & 2787 & 2787 & 2787 & 2787 & 2787 & 2787 & 2787 & 2787 \\
\hline
\end{tabular}


Table 14: Effect of overall CSP and its components on market beta derived from Fama French 5 Factor Model

This table presents 2SLS coefficient results for the estimated CSP variable based on the Fama French five-factor model per overall CSP or its components, and per region. The estimation is based on daily stock and factor returns. Betas above the significance level of $10 \%$ were excluded to reduce noise. CSP Coefficients are marked as significant on the level of $1 \%(* * *), 5 \%(* *)$ or $10 \%(*)$ when the $p$-value is below these levels.

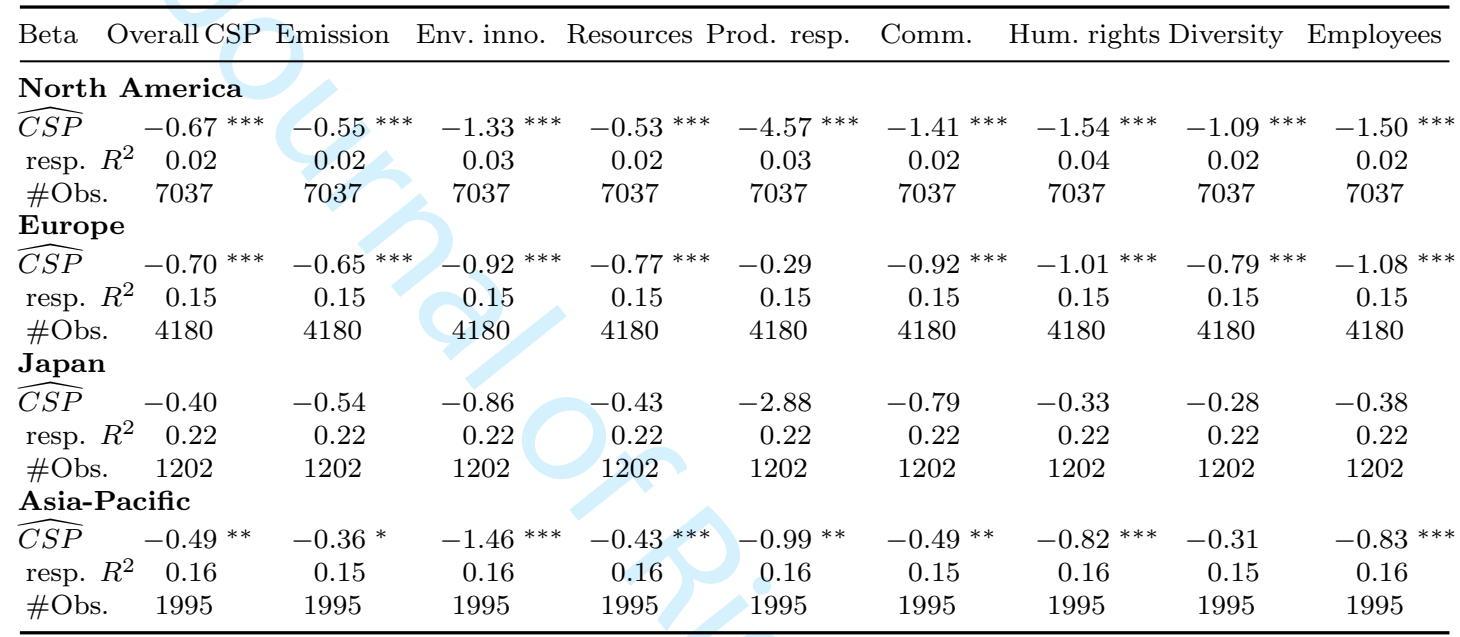


Figure 1: Incremental impact of overall CSP and its components on beta This set of plots shows the incremental impact of CSP on firm beta based on models including both a linear CSP and a squared CSP measure. Each of the plots considers one CSP category, such as overall CSP or single categories (e.g., emission), and shows a separated line for each of the four regions.
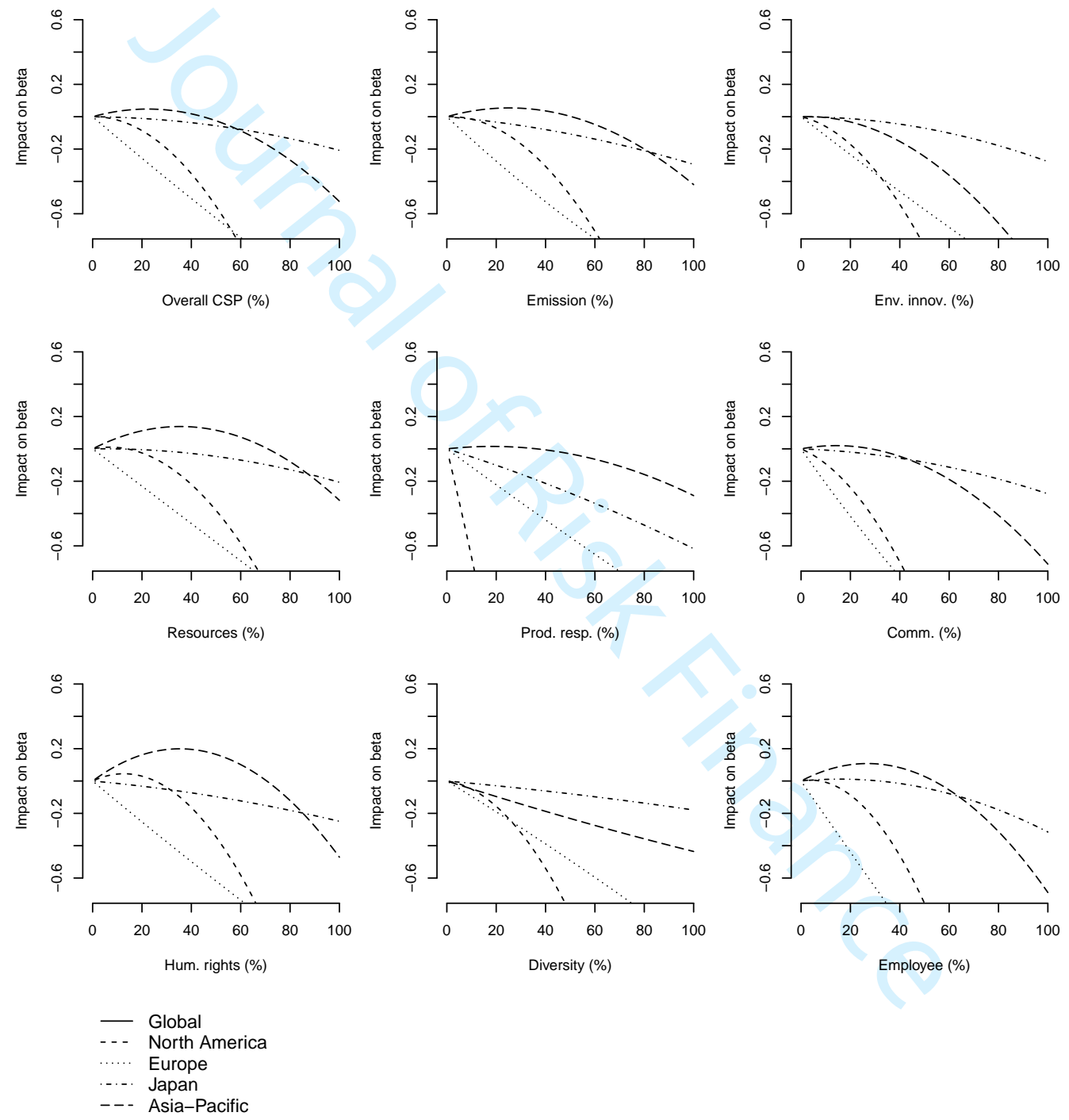
Table 15: Effect of overall CSP and its components on market beta derived from the international CAPM

This table presents 2SLS coefficient results for the estimated CSP variable based on the international CAPM model per overall CSP or its components, and per region. The estimation is based on weekly stock and factor returns. Betas above the significance level of $10 \%$ were excluded to reduce noise. CSP Coefficients are marked as significant on the level of $1 \%(* * *), 5 \%(* *)$ or $10 \%\left(^{*}\right)$ when the $p$-value is below these levels.

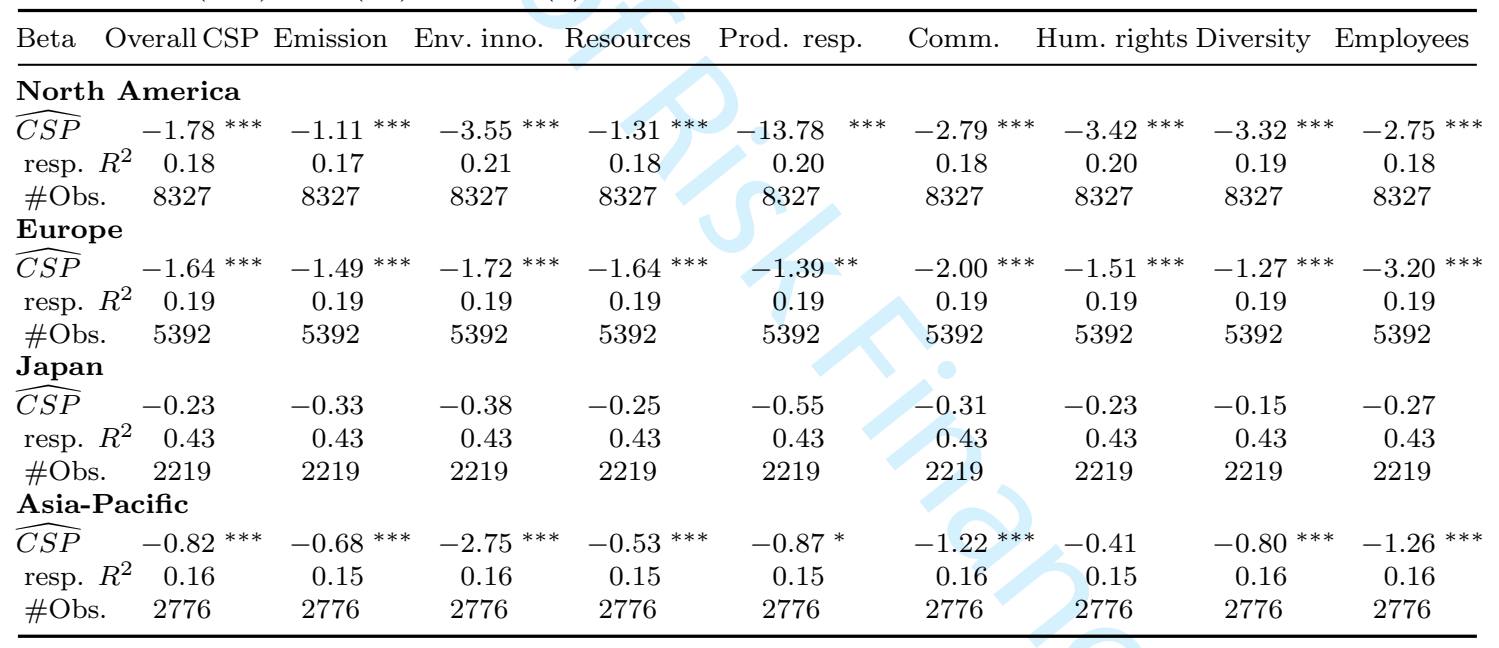




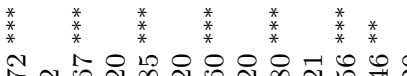

Mि

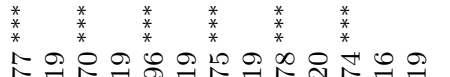

भi

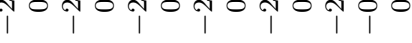

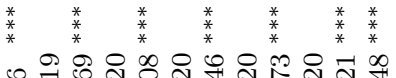

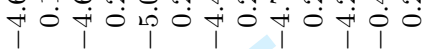

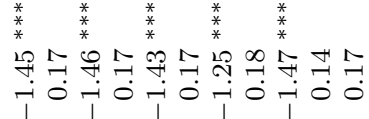

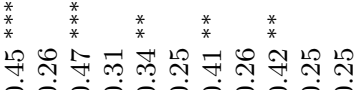

0 00000000

๓

000000

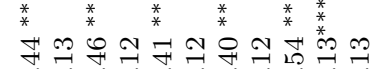

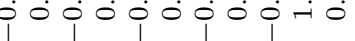

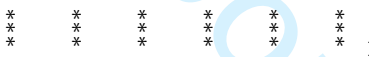

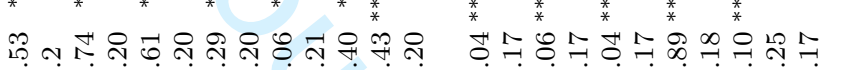

i

में

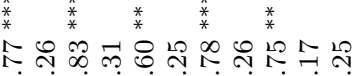

$\dot{0} 0 \dot{0} 0 \dot{0} 0 \dot{0} 0 \dot{0} 0 \dot{0}$

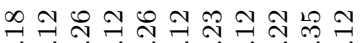

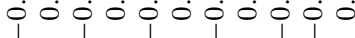

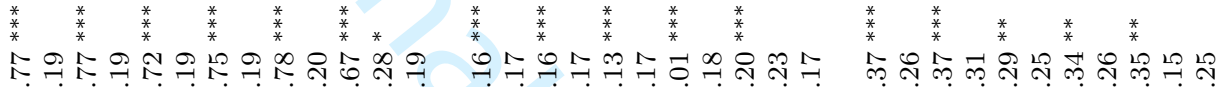
Нं

í0 000000

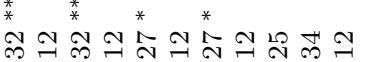
io

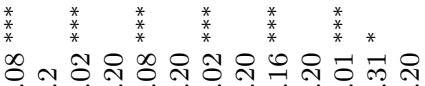

mo pop

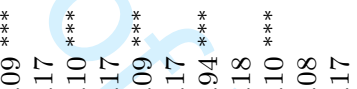

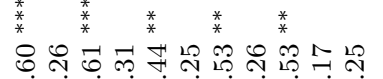

10

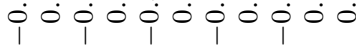

* * * * * * * * * * * * *

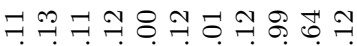

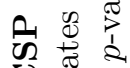

寻

记政

记

*

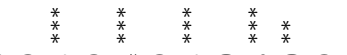

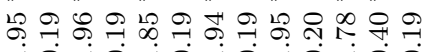

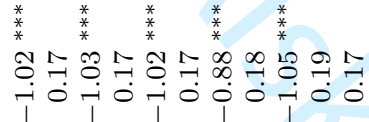

苂

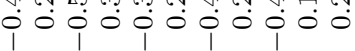

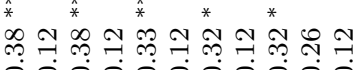
i 000 O

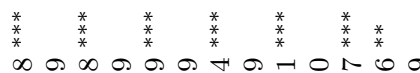
ส่ง hò

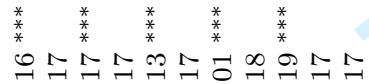

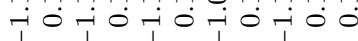

\section{* * * * * * * * * * * * * * * * *}

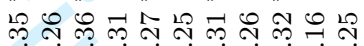

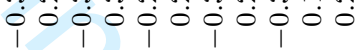

* $\stackrel{*}{*} \quad * * *^{*} \quad *$ *

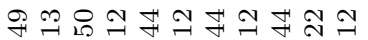
$\dot{0} 0 \dot{0} 0 \dot{0} 0000$

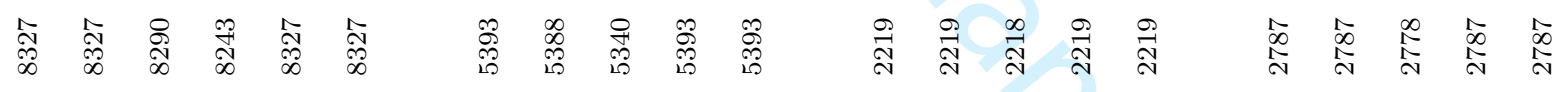
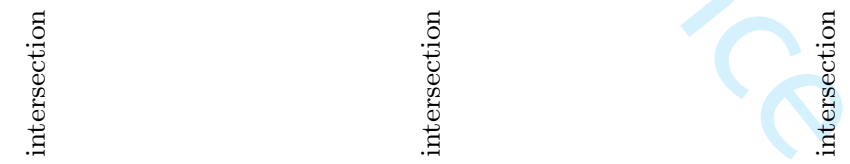

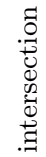

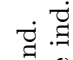

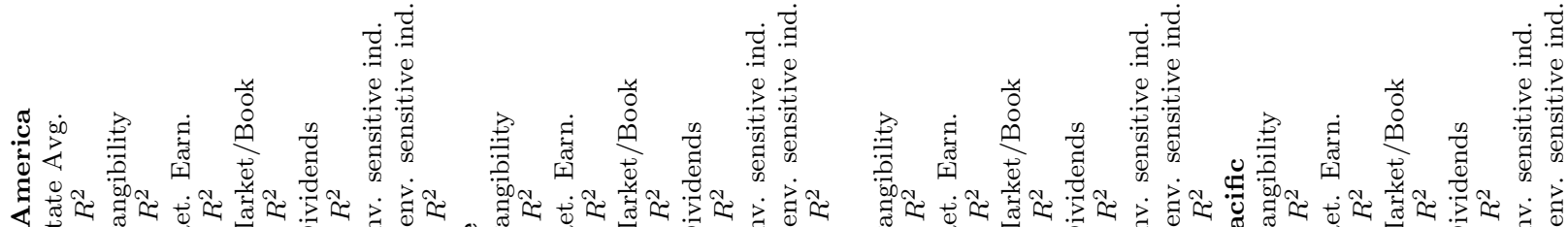

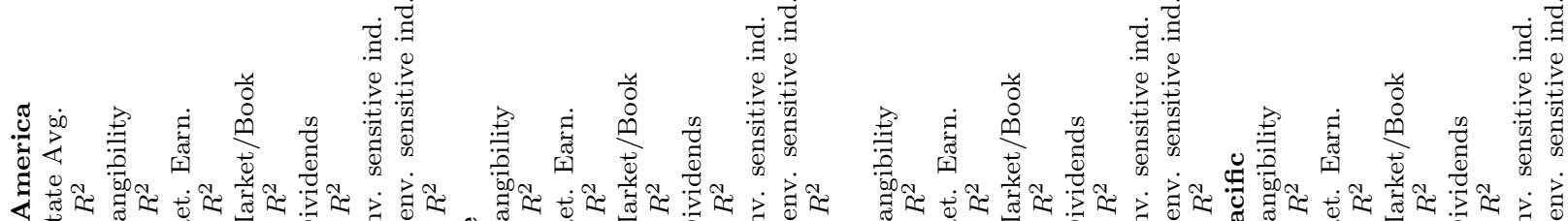

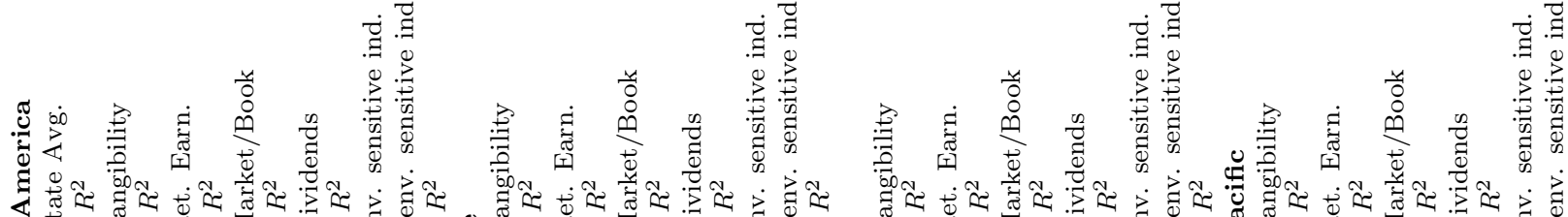

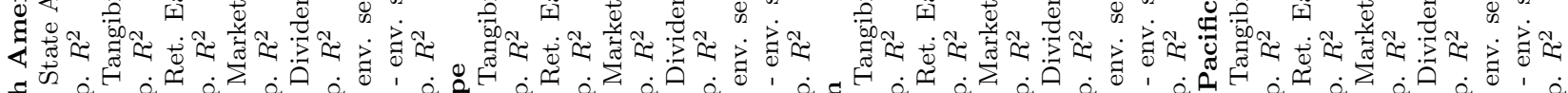

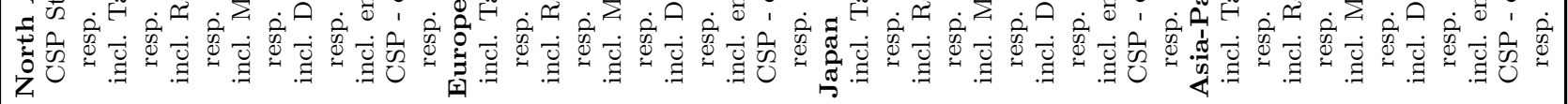



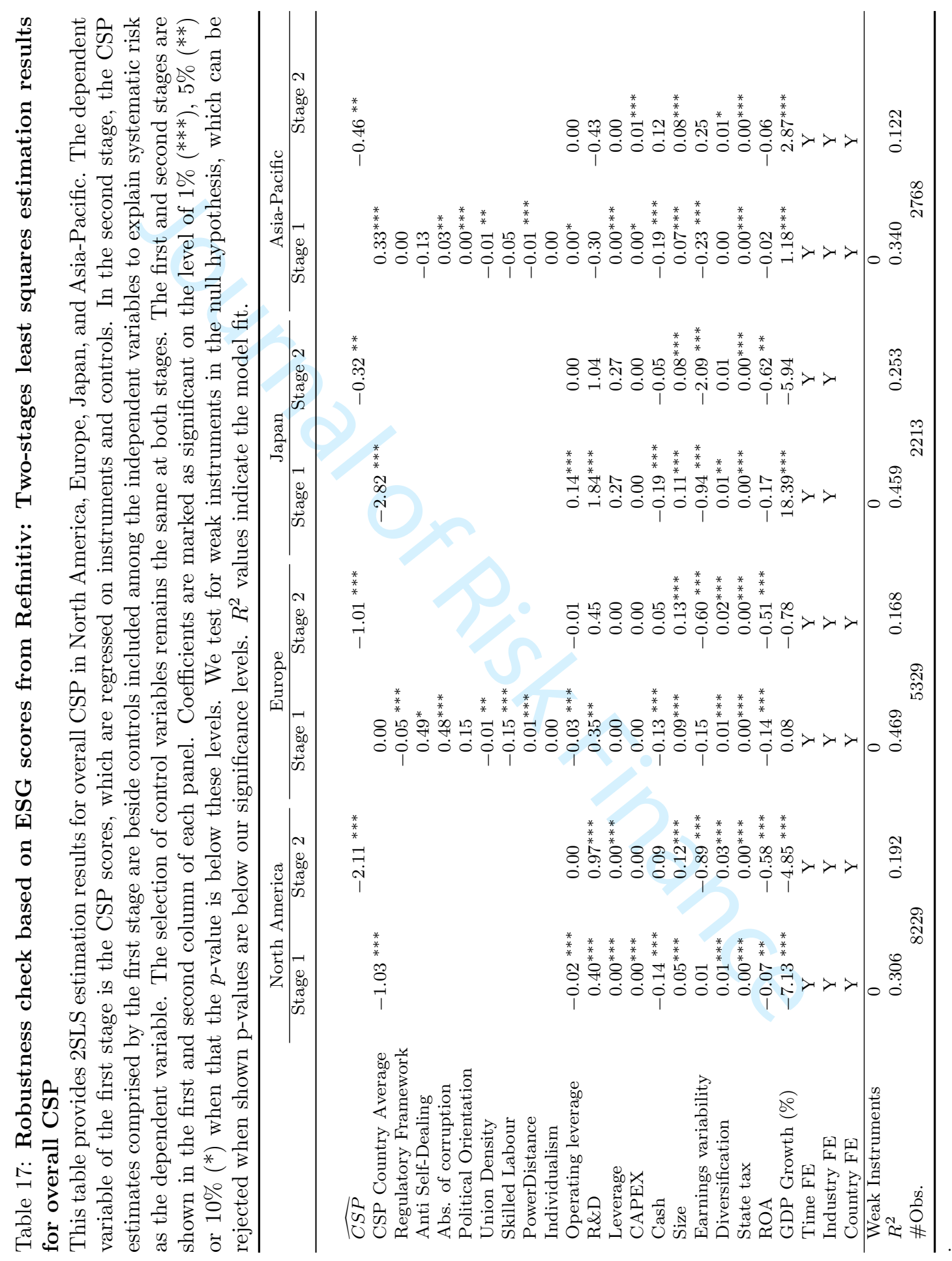


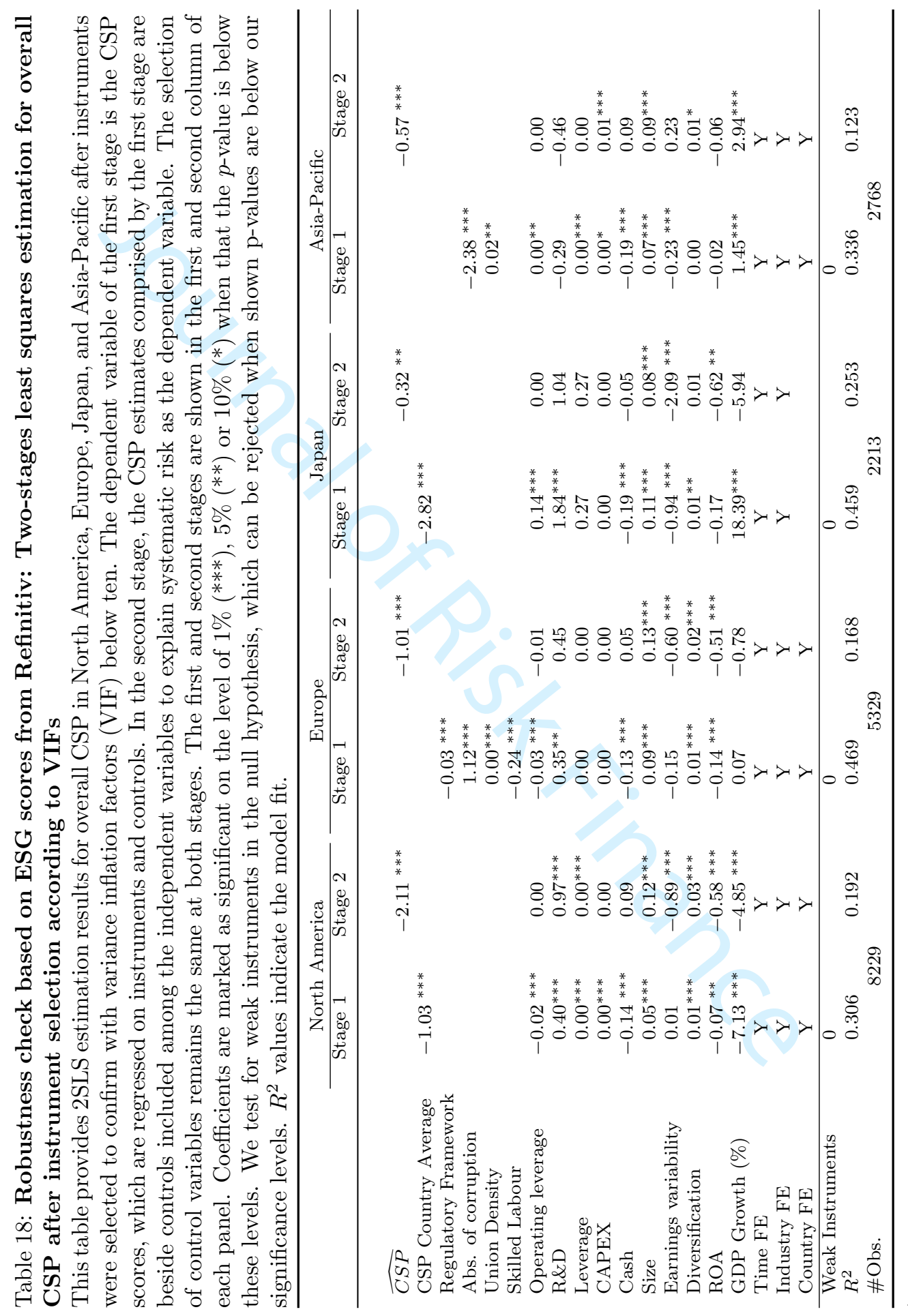




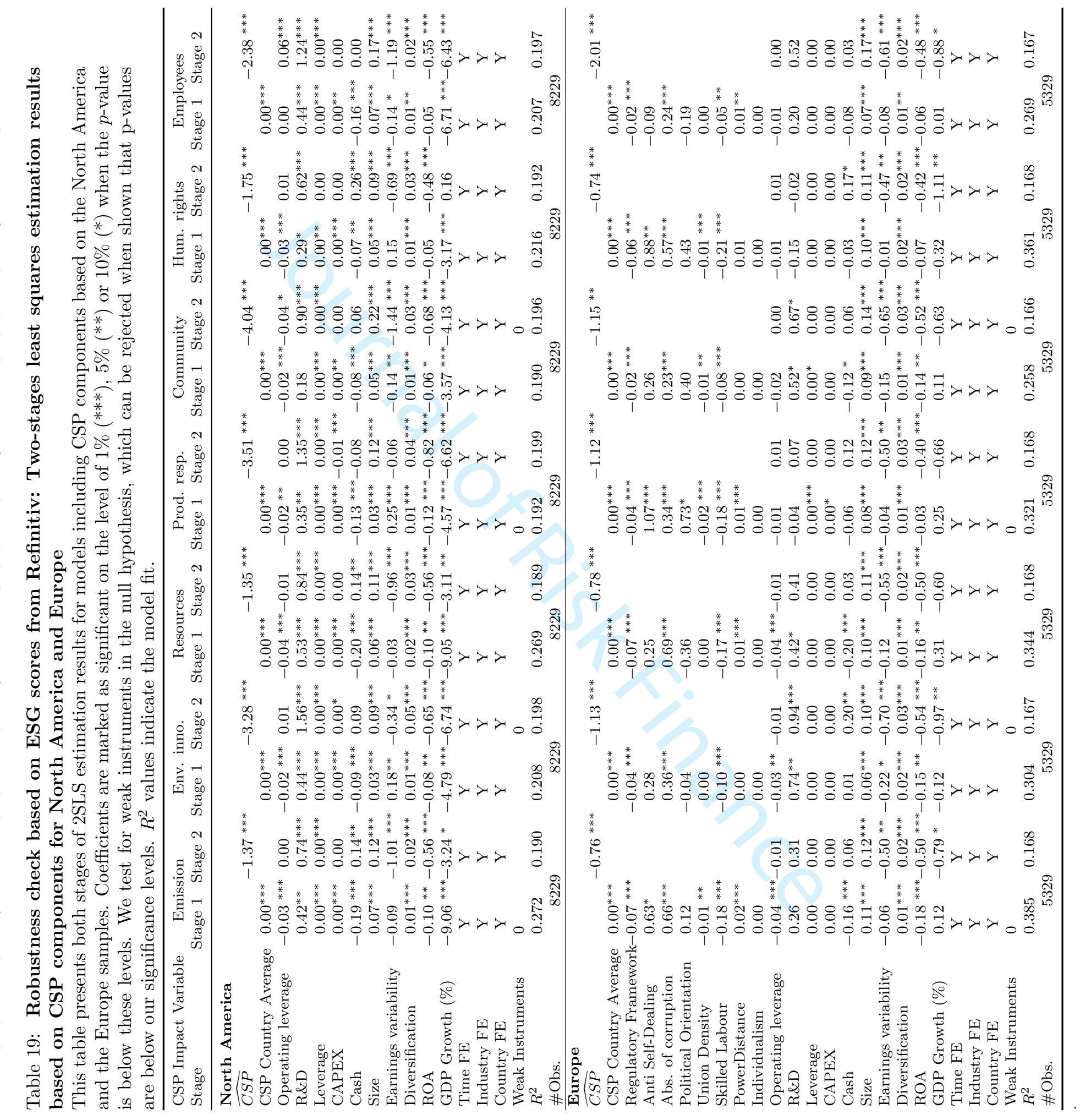




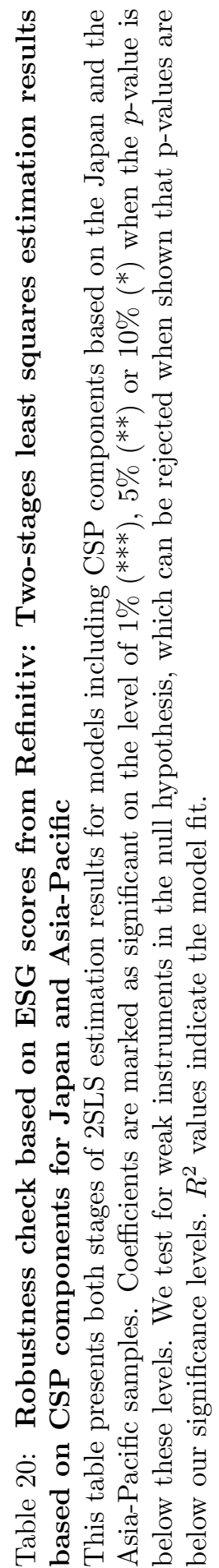

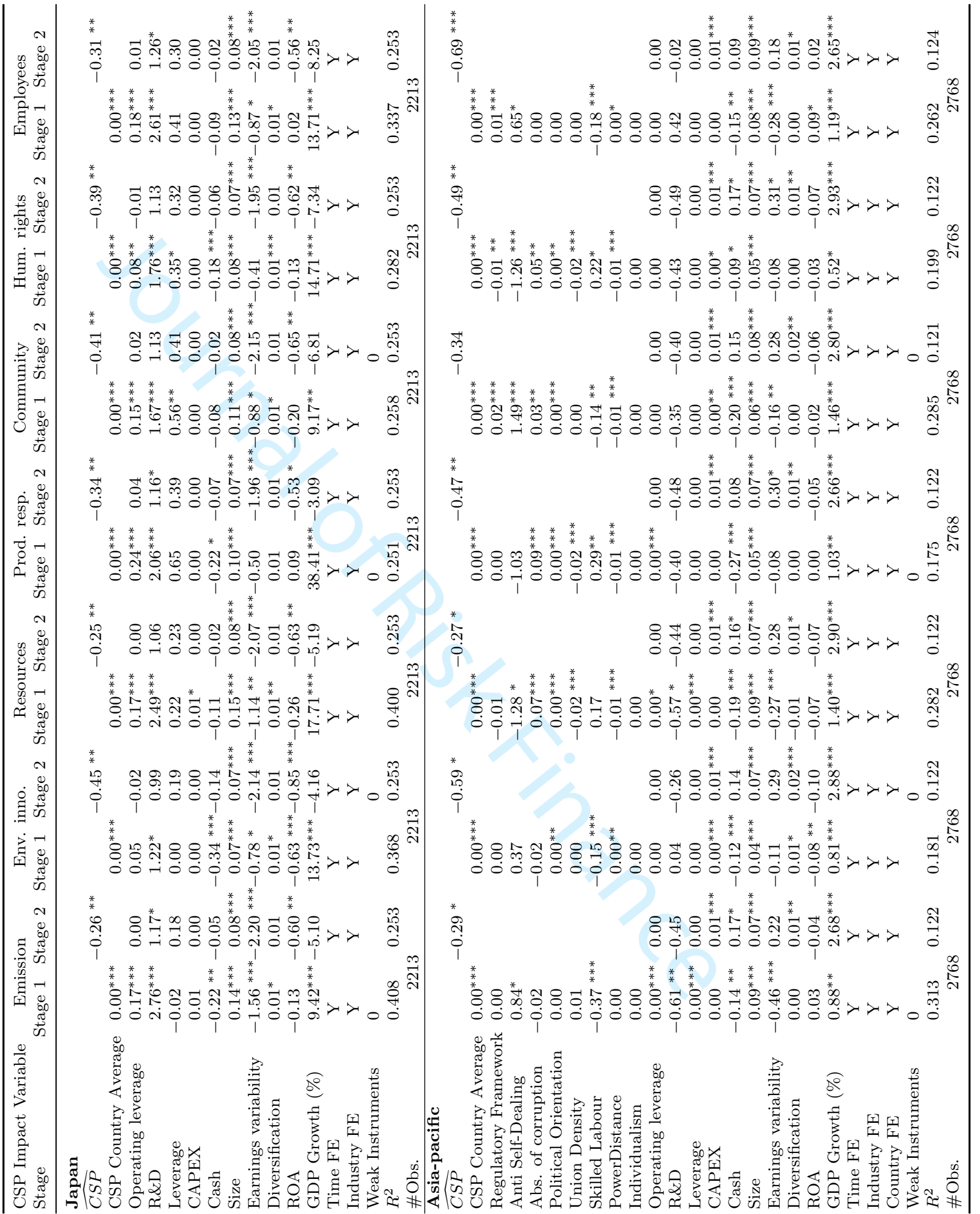

